\title{
DOUBLY FLAWED: \\ CANADA'S REFUGEE DETERMINATION SYSTEM IN A POST 9/11 ERA \\ by
}

Sandra-Marie Virgili, Honours BA, University of Toronto, 2012

\author{
A Major Research Paper \\ presented to Ryerson University \\ in partial fulfillment of the requirements for the degree of \\ Master of Arts \\ in the Program of \\ Immigration and Settlement Studies
}

Toronto, Ontario, Canada, 2013

CSandra-Marie Virgili 2013 
AUTHOR'S DECLARATION FOR ELECTRONIC SUBMISSION OF A MRP

I hereby declare that I am the sole author of this Major Research Paper. This is a true copy of the MRP, including any required final revisions.

I authorize Ryerson University to lend this MRP to other institutions or individuals for the purpose of scholarly research.

I further authorize Ryerson University to reproduce this MRP by photocopying or by other means, in total or in part, at the request of other institutions or individuals for the purpose of scholarly research.

I understand that my MRP may be made electronically available to the public.

Sandra-Marie Virgili 


\title{
DOUBLY FLAWED: \\ CANADA'S REFUGEE DETERMINATION SYSTEM \\ IN A POST 9/11 ERA
}

\author{
Sandra-Marie Virgili \\ Master of Arts 2013 \\ Immigration and Settlement Studies \\ Ryerson University
}

\begin{abstract}
Canada's refugee determination system not only remains vulnerable to terrorist exploitation but also fails to assist legitimate refugees in a post 9/11 era. Through conducting an analysis of the Immigration Act, this paper exemplifies how, historically, Canada has had difficulty in regulating refugee migration into the country. The Immigration and Refugee Protection Act was implemented as a means of overhauling the Immigration Act, making for a more secure Canada. Although this newer legislation is successful in maintaining the rights of refugees, especially with the verdict of Singh v. Minister of Employment and Immigration, it still lacks numerous safeguards. The lack of an adequate detainment policy, manifestly unfounded policy, the designated country of origin policy, the appeals process, and delayed deportation of foreign nationals leaves the system vulnerable to abuse by terrorists. Ultimately, Canada has become a potential base for terrorists who have access to the entire international community within the safety of Canadian borders.
\end{abstract}

\section{Key Words:}

Refugee policy, terrorism, national security, refugee camps, refugee rights 


\section{ACKNOWLEDGEMENTS}

I take this opportunity to thank several people who were instrumental in the writing of this MRP. I would like to thank my supervisor, Dr. Arne Kislenko, for his constant encouragement, patience, and positivity throughout this entire process. I sincerely appreciate his thoughtful input and immense knowledge on the topic. I also would like to thank Dr. Myer Siemiatycki for his insightful feedback and comments. A special thanks to Cesare Plastina, who as a good friend, was always willing to assist me. Last but certainly not least, this MRP could not be completed without the endless love and support from my amazing parents, brother, friends, and family. 


\section{LIST OF APPENDICES}

Appendix 1: Statutory Provisions (Excerpts of Relevant Provisions)

Appendix 2: Canadian Cases Cited

Appendix 3: Statutes Cited 
Canada, a nation of immigrants, has a very interesting immigration history. Historically, immigration to Canada was encouraged by the government for several purposes including nation-building and economic growth. Canada's doors were also open to people in need of a new home, such as migrants fleeing Ireland due to the potato famine. Throughout most of Canadian immigration history, immigration policy constantly demanded certain "types of people" to settle Canada. Selectivity was exemplified through the Chinese head-tax, the continuous journey requirements used to exclude South Asians, as well as the government's prohibition of Jewish refugees during the Second World War. Many of Canada's past immigration policies can be deemed discriminatory.

However, Canada has certainly come a long way from its exclusionary policies and has slowly opened its doors to migrants from every corner of the world regardless of race, religion, or socioeconomic status. Additionally, immigration policy evolved to become more inclusive to refugees, allowing Canada to fulfill its international obligation to accept those being persecuted in their homelands. Economic development is still a very important priority for the government as most immigrants come to Canada under the economic class, including temporary foreign workers, live-in caregivers, and skilled migrants. ${ }^{1}$ However, the government has additional competing obligations. Specifically, national security has become increasingly relevant in the last decade, especially after the $9 / 11$ terrorist attacks. Giving a precise definition to national security is difficult, as it is inclusive of numerous and diverse aspects. Simply put, it can be defined as securing collective society ${ }^{2}$ including the protection of national interests, values, democracy, our governmental institutions, infrastructure, and the physical protection of the

\footnotetext{
${ }^{1}$ Peter Rekai, "US and Canadian Immigration Policies- Marching Together to Different Tunes," C.D. Howe Institute Commentary: the Border Papers, no. 171 (2002): 9, http://www.cdhowe.org/pdf/temp/rekai.pdf (accessed June 2, 2013).

${ }^{2}$ Daniel Stoffman, Who Gets In: What's wrong with Canada's Immigration Program and how to fix it, (Toronto: Macfarlane Walter \& Ross, 2002), 11.
} 
people against any external or domestic threat. As the world is in a constant state of change, the security threats are neither concrete nor definitive. Rather, threats are constantly changing and evolving.

In examining the post 9/11 era, this essay focuses on maintaining Canadian national security, specifically through defending against terrorism. Terrorism is overblown by the media, thus it stands out in the public mindset, where the public would expect such threats to be prioritized. Some scholars would argue that this issue is an excessive fixation, using examples such as infrastructure failure as a more harmful national security issue. Notwithstanding this contention, terrorism should not be ignored. Terrorism represents a different priority within national security, involving different groups, departments, and funds. Terrorism should not be underestimated as it has broader security implications, including various links with organized and international crime.

Terrorism in and of itself is constantly changing through identifying new targets, gathering new members, and creating new strategies of attack. ${ }^{3}$ Terrorism is certainly not a new phenomenon originating from September 11, but has existed in various forms throughout history. Occasionally transnational in nature, terrorism stretches across borders and engages targets on one side of the world directed by perpetrators from the other side. Resultantly, national security efforts must evolve with security threats. Yet, in post-9/11 Canada, the Canadian government faces novel challenges to its ability to provide a high degree of national security. One method adopted by the Canadian government was to continue to legislate security through the immigration system, specifically with the implementation of new legislation, the Immigration and Refugee Protection Act (IRPA).

\footnotetext{
${ }^{3}$ Megan Yasenchak, Jennifer Giglio, and Margaret Paxson, Woodrow Wilson International Center for Scholars, "National Security and Human Rights," last modified October 2006, 10, www.wilsoncenter.org/sites/default/files/KI_G8.pdf (accessed July 21, 2013).
} 
Echoing the sentiments of new post-9/11 legislative challenges, Hanson Sone suggests that Canada's initial responses to terrorism indicate that constitutionalism and democracy will have a hard time meeting the threat of terrorism while maintaining their "supposedly cherished principles" ${ }^{4}$ Although there is tension between national security and human rights, it does not necessarily indicate that the two concepts are mutually exclusive. The concepts of "national security" and "human rights" are used to categorize arguments of this paper. In fact, the two concepts are co-dependent and exist as two of the main responsibilities of the government which must be simultaneously upheld. As will become clear in the following study, a liberal democracy such as Canada must balance on one hand its dedication and responsibility to uphold individual rights under the Charter of Rights and Freedoms, ${ }^{5}$ and on the other, its responsibility to ensure the safety and national security of its citizens and territory against the threats of global terrorism. Evidently, a challenge is faced by the government as these two obligations must be fulfilled in tandem with admitting refugees, in order to adhere to international and humanitarian obligations. The events of 9/11 intensified an already restrictive climate for refugees and asylum seekers, especially through the implementation of the Immigration and Refugee Protection Act. ${ }^{6}$

Both national security and human rights advocates have scrutinized the entrance process for refugees under the IPRA. "Human rights" or "refugee advocates," as they will be referred to in the paper, base their arguments on more lenient entrance policies as well as increased rights for refugees. More specifically, human rights advocates take issue with the broad definition of terrorism and equality rights violations infringed upon by the IRPA. In using securitization theory, human rights advocates attempt to demonstrate how the refugee has been wrongly

\footnotetext{
${ }^{4}$ Hanson Njoh Sone, The Detention and Deportation of Convention Refugees on Grounds of Criminality and National Security in Canada: Challenges and Justifications, (A Thesis Submitted to the Faculty of Graduate Studies: Graduate Program in Law. 2008), 2.

${ }^{5}$ Hereinafter referred to as the Charter.

${ }^{6}$ Hereinafter referred to as the IRPA.
} 
deemed a terrorist and how the government implemented the IRPA to limit the rights of migrants post $9 / 11$. It is beyond the scope of the argument to identify and thoroughly analyze all features of the entire refugee system, so only the most problematic aspects which national security and human rights advocates take issue with will be discussed. Ultimately, this paper will determine if Canada's refugee determination system is successful in the protection of human rights, national security, and the admittance of legitimate refugees into Canada in a post 9/11 era.

In order to clearly illustrate this argument, a particular organization will be followed. An historical analysis of the Immigration Act will describe how an era of security concerns began. Following that, there will be two sections devoted to the two main arguments that this study puts forth. Firstly, this study will address the alleged human rights violations by the IRPA, as argued by human rights and refugee advocates, concerning issues about the definition of terrorism and equality rights. Secondly, the national security debate will be presented through demonstrating that Canada's refugee determination system facilitates the entry of terrorists into Canada. This is evidenced through a lack of appropriate detainment policy, manifestly unfounded policy, designated country of origin policy, the appeals process, and the delayed deportation. However, first and foremost, there are several parameters and relevant definitions that this study will use.

In regards to terminology, the refugee determination system has engendered some confusion. Several clarifications and definitions of terms are offered here as they will be used extensively throughout this paper. Firstly, a refugee differs greatly from an "asylum seeker." An asylum seeker is not a refugee, but intends to claim refuge, asking for the protection of a host country. A determination must be made as to whether or not the situation of an asylum seeker fits the definition of a refugee. Referring to an asylum seeker as a refugee implies that an asylum seeker has a legitimate claim to afford protection from Canada. Asylum seekers rightfully 
become "refugee claimants" after landing in a desired country, and making a refugee claim. Interestingly, where Canada classifies individuals as refugee claimants, other countries classify the same claimants as "asylum seekers." Martin Collacott believes that "refugee claimant" should be reserved for individuals who arrive in Canada "on the basis of claims that they have been persecuted in their home countries and that it is unsafe to return". 7

Canada's official definition of refugees is based on international conventions. As defined by the 1951Convention and Protocol Relating to the Status of Refugees ${ }^{8}$ a refugee is a person who "has left his or her country and cannot return because of a well-founded fear of being persecuted due to race, religion, nationality, political opinion or membership of a particular social group." If a person fits this definition, they are accepted into a country as a refugee, having a legitimate claim. This is a legal status, approved by the government and is not given automatically to an individual simply making a claim. Canada is also obligated to give refuge to "persons in need of protection," who are defined differently than refugees by the IRPA. Under S.97 (1) of the IRPA, a person in need of protection is a "person in Canada whose removal to their country or countries of nationality or, if they do not have a country of nationality, their country of former habitual residence, would subject them personally to danger of torture, a risk to their life, or a risk of cruel and unusual treatment or punishment." 9 Thus, a person in need of

\footnotetext{
${ }^{7}$ Martin Collacott, “Canada's Inadequate Response to Terrorism: the Need for Policy Reform," Fraser Institute Digital Publication, 2006: 1, http://www.fraserinstitute.org/WorkArea/DownloadAsset.aspx?id=2334. See also, Stephen Gallagher, "Canada's Broken Refugee Policy System," In Immigration Policy and the Terrorist Threat in Canada and the United States, edited by Alexander Moens, and Martin Collacott, 56, Vancouver 2008 and Arne Kislenko, "Guarding the Border: Intelligence and Law Enforcement in Canada's Immigration System," in The Oxford Handbook of National Security Intelligence, edited by Loch Johnson, New York: Oxford University Press, 2010, 319.

${ }^{8}$ United Nations High Commissioner for Refugees. Convention and Protocol Relating to the Status of Refugees 1951, accessed June 12, 2013, http://www.unhcr.org/3b66c2aa10.html, 5.

${ }^{9}$ Immigration and Refugee Protection Act, S.C., 2001, S.97(1).
} 
protection might not meet the definition of a Convention refugee per say, but is in a "refugeelike" situation and is deserving of Canadian protection. ${ }^{10}$

However, several scholars take issue with how Canada defines a refugee. Peter Rekai, Stephen Gallagher, and Martin Collacott believe that Canada's definition of refugee, in comparison to other nations, stretches far beyond the Convention's notion of refugee. Canada's definition includes a "broader interpretation of concepts of persecution, state protection, political opinion and religious belief"' to the extent where the definition of 'refugee' has become meaningless and arbitrary. Thus, Canada gives refugee status to individuals that other countries would not define as Convention refugees, resulting in a blur between claims. For example, Canada would categorize homosexuals as members of a particular social group. Scholars argue there is no distinction between a Convention refugee and individuals making economically motivated claims. ${ }^{12}$ As a result, more individuals are able to fit within the scope of a refugee, even though they might not be considered refugees by international standards or the Convention's definition. By stretching this definition, terrorists have a more expanded means of gaining access into the country as their claim can fall under numerous categories. Conversely, human rights advocates would argue that such an expansive definition of refugee is necessary in today's world as it reflects "complex modern global politics, with its varying and often subtle forms of oppression and persecution." 13 The expanded definition allows Canada to meet its international obligations under the 1984 Convention Against Torture, protecting those who might not fit the standard definition of Convention refugee but are subject to torture or cruel and

\footnotetext{
${ }^{10}$ Canadian Council for Refugees, "Talking about Refugees and Immigrants: A Glossary of Terms," accessed June 24, 2013, http://ccrweb.ca/glossary.PDF

${ }^{11}$ Rekai, "US and Canadian Immigration Policies- Marching Together to Different Tunes," 12.

${ }^{12}$ Collacott, “Canada's Inadequate Response to Terrorism: the Need for Policy Reform,” 30. See also, Rekai, "US and Canadian Immigration Policies- Marching Together to Different Tunes," 13.

${ }^{13}$ Ibid., 13.
} 
unusual punishment. ${ }^{14}$ In contrast, Alice Edwards (in citing Joan Fitzpatrick) would argue that the definition of a refugee is actually too vague and can be manipulated by states to control the entry of people within their territories. ${ }^{15}$

Although the definitions between a Convention Refugee and a refugee claimant seem straightforward, one of the main debates within this paper takes root in the definitional difference between these two terms as well as how Canada responds to these two very different types of individuals. Is the Canadian government actually assisting genuine Convention refugees or is it simply responding to individuals who appear at the border, making a refugee claim? Moreover, do individuals making refugee claims fit the Conventions definition of a refugee? Is the Canadian government acting in a responsive manner to individuals arriving at border or is it taking initiative in seeking legitimate, Convention refugees and assisting those that have no means or money to travel to Canada? This argument will be thoroughly addressed at a later point of the paper. Also, this study will not include claims made by claimants to the Canadian embassy in a foreign country. Rather, it will focus only on refugee claims made within Canada by asylum seekers entering by boat, plane, or at the US-Canada land border. Individuals within the country's borders are physically present in Canada, thereby representing a tangible and potential threat.

An additional concern posed by the structure of the refugee determination system is its potential vulnerability to terrorism. "Terrorism" is utilized liberally by both human rights and national security advocates. As there is no internationally accepted definition for terrorism that is, the United Nations has not officially defined terrorism in any of its declarations or articles, the

\footnotetext{
${ }^{14}$ Ninette Kelley and Michael Trebilcock, The Making of the Mosaic: A History of Canadian Immigration Policy. (Toronto: University of Toronto Press, 2000), 441.

${ }^{15}$ Alice Edwards, "Human Security and the Rights of Refugees: Transcending Territorial and Disciplinary Borders," Michigan Journal of International Law, 30, no. 3 (2009): 795.
} 
legal definition of terrorism as defined in the Canadian Criminal Code will be the standard definition used throughout this paper. Section 83 of the Criminal Code defines terrorist activity as an action which violates any one of the ten listed UN terrorism conventions including:

"acts committed in or outside of Canada in whole or part for political, religious or ideological purposes, with the intention of intimidating the public with regards to security including economic security or compelling a person a government to do or to refrain from doing any act [...] that intentionally causes death or serious bodily harm to a person by the use of violence, endangers a person's life, causes a serious risk to the health or safety of the public or any segment of the public, substantial property damage or causes serious interference of an essential service, facility or system..." 16

This definition will be analysed in depth when discussing the human rights implications it carries. This paper is limited to terrorists who have migrated to Canada (e.g. individuals considered asylum seekers, refugee claimants, refugees, or illegal immigrants), born and raised in a foreign country and have ties to terrorist organizations. This analysis excludes what can be called "homegrown" terrorism; terrorism committed by citizens of a nation.

Not surprisingly, words used to describe "terrorists" differ between human rights and national security advocates. Where national security advocates deem an individual a terrorist, human rights activists sometimes depict individuals as "freedom fighters," "community activists" or "political advocates" fighting for "the people." At times, human rights advocates remove the criminality from the definition of terrorist. The terrorist becomes more "appealing," portrayed as heroes or individuals who are fighting for the common good of their people. Human rights advocates believe the terrorist is dehumanized and demonized having the potential to create "imminent, alien danger." 17 A mentality of "us vs. them" exists between the terrorist and the "regular" citizen, where the terrorist is seen as sub-human, "characterized as a transient

\footnotetext{
16 Criminal Code, 1985, S.83.

${ }^{17}$ Faisal Bhabha, "Tracking 'Terrorists' or Solidifying Tereotypes? Canada's Anti-Terrorism Act in Light of the Charter's Equality Guarantee," Windsor Review of Legal and Social Issues, 16, no. 96 (2003): 105.
} 
outsider having little regard for life, a wandering predator with a taste for blood." ${ }^{18}$ Regardless of whether or not the vocabulary to describe terrorists is dehumanizing, the act they are committing against other citizens of the world, is inhumane and atrocious. Terrorism is not just killing people but also encompasses "psychological reverberations in society" in which attacks display "ruthlessness, premeditation, and technical capability."19 Terrorism attempts to inflict physical, emotional or psychological terror upon a population. The vocabulary to describe these individuals rightfully describes their actions. Human right advocates reviewed in this paper may describe terrorists in a way that removes the intensity and severity of the crimes.

As described, terrorism is a very unique type of crime. Maintaining the national security of Canada is one of the main responsibilities of the government and also determines the success of the refugee determination system. Throughout the literature assessed for this paper, national security fails to receive a standard or clear definition. Authors presuppose that the reader understands that national security inherently means protection of society from terrorist attacks. Generally, national security refers to the capability and duty of governments to protect the societies they govern. Daniel Stoffman ${ }^{20}$ states that national security means keeping "collective" society safe, by which "collective interest overrides special interests." However, a more comprehensive definition of national security is needed to fully understand its implications. The protection of "collective society" must include everything which comes together to make up a society including the economy, infrastructure, amenities, citizens, and government. The definition must acknowledge that everything is interrelated, where an attack on one aspect of society will consequently affect another. For example, if there is a nuclear explosion, not only

\footnotetext{
18 Ibid.

${ }^{19}$ Risa Brooks, "Muslim 'Homegrown' Terrorism in the United States: How Serious Is the Threat?" International Security, 36, no. 2 (2011): 39-40.

${ }^{20}$ Stoffman, Who Gets In: What's wrong with Canada's Immigration Program and how to fix it, 11.
} 
will people be physically harmed and killed, but infrastructure (including hospitals, schools, police/fire stations, etc.) will also be destroyed, and unavailable to the people. Additionally, the environment would inevitably be damaged which has an effect on food supply, air quality, and water quality. Consequently, this has detrimental outcomes to the human population, even though citizens are not directly affected, the nation's quality of life will be substantially damaged. This definition is more useful in the context of this paper as it encompasses everything the nation represents and is an adequate inclusion of what Canadian policies must defend.

In addition to national security, the government must uphold the rule of law in maintaining human rights of individuals, specifically protecting civil liberties, rights and freedoms as outlined by the Charter. Human rights are principles which are "true and valid for all people, in all societies, under all conditions of economic, political, ethnic and cultural life...these principles are present in the very fact of our common humanity" as stated in Max Stakehouse's book, and referenced in Crépeau and Nakache's article. ${ }^{21}$ As per international human rights declarations, individuals are entitled to basic human rights, regardless of whether or not they are authorized to settle within a country. Human rights are based on the notion that "human beings possess fundamental human rights by virtue of their humanity alone," which cannot be alienated. ${ }^{22}$ Moreover, civil liberties, rights, and freedoms are described as negative rights: protecting citizens from the "all-powerful" state apparatus. Negative rights are "basic, equal, and inalienable rights" that are essential to human dignity. ${ }^{23}$ Upholding negative rights is

\footnotetext{
${ }^{21}$ Max L. Stackhouse, Creeds, Society and Human Rights: A Study in Three Cultures (Grandd Rapids, MI: William B. Eerdmans Publishing, 1984), 1, quoted in Francois Crépeau and Delphine Nakache, "Controlling Irregular Migration in Canada: Reconciling Security Concerns with Human Rights Protection," IRPP Choices, 12, no. 1 (2006): 4.

${ }^{22}$ Paul Hoffman, "Human Rights and Terrorism,” Human Rights Quarterly, 26 (2004): 939.

${ }^{23}$ United Nations, “The Universal Declaration of Human Rights," last modified 2013, accessed June 26, 2013, http://www.un.org/en/documents/udhr/index.shtml
} 
accomplished by setting limitations on governmental powers as a means to mitigate potential abuses of power and mitigate unnecessary interference in the private lives of citizens.

Indeed, national security and human rights complement each other. Both are essential in keeping a society free and safe. ${ }^{24}$ National security can only be upheld in an environment which respects the rule of law and rights of the people. If the rights of the people are compromised, a draconian state exists, and one will inevitability question whether or not the state is actually 'secure.' Conversely, national security must be preserved to protect governmental institutions, infrastructure, and democracy to actually allow government personnel to uphold the rule of law and the rights and freedoms of citizens. In fact, national security serves to protect the democratic values and civilian rights that Canada proudly stands for. The government walks a fine line in attempting to coordinate these two responsibilities. Yet, to combat terrorism, both national security and human rights must be preserved. The evolution of policy and its protection of rights and national security become clearer when analysing Canada's historical response to refugees.

Legislatively, the 1970s, 1980s, and 1990s was a significant timeline for the development of refugee policy. During this period Canada was not only exposed to security threats, but was also obliged to meet international refugee acceptance quotas. During the 1970s and 1980s, Canada took a humanitarian stance towards refugees as the Immigration Act of 1976 was motivated by concerns that the system should reflect Canadians values, offering protection to refugees. Security was not a dominant motive of immigration policy. ${ }^{25}$ The Immigration Act $^{26}$ was monumental because for the first time in Canadian history, this legislation overtly outlined that refugee resettlement was an integral aspect of immigration policy, displaying in writing

\footnotetext{
${ }^{24}$ Yasenchak et al., "National Security and Human Rights," 9, 18.

${ }^{25}$ Sandy Irvine, "Canadian Refugee Policy: Understanding the role of international bureaucratic networks in domestic paradigm change," in Policy Paradigms, Transnationalism, and Domestic Politics, edited by Grace Darlene Skogstad, 7 (Toronto: University of Toronto Press, 2011).

${ }^{26}$ Hereinafter referred to as the Act.
} 
Canada's commitment to humanitarian obligations. Moreover, the Act accommodated increasing global refugee populations. Between 1970 and 1993 there was a surge in the global refugee population from 2.5 million to over 18 million. ${ }^{27}$ Family class, assisted relatives, independent class, and a humanitarian class were included under the new Act. Specifically, the humanitarian class consisted of "refugees as defined in the 1951 United Nations Convention relating to refugees [as well as] persecuted and displaced persons who do not qualify as refugees under the UN definition but who are members of a designated class, created by the Cabinet for humanitarian reasons." ${ }^{28}$ The Act provided three routes of refugee admission inclusive of in-land determination, resettlement through private and government sponsorship, and special programs for people from specified countries. ${ }^{29}$

However, concern during the 1980s increased as the Act became criticized for opening the doors to a flood of spontaneous refugee arrivals many of whom had illegitimate claims. Before the implementation of the Act, migrants claiming refugee status at Canadian borders numbered in the hundreds but grew to several thousand in the 1980s, peaking at more than 37 000 in $1992 .^{30}$ Between 3400 and 5200 claimants arrived between 1982 and 1984 alone compared to the 200 to 400 claimants in the late $1970 \mathrm{~s}^{31}$ There are numerous reasons substantiating the dramatic increase in claims as well as the consequent backlog. These include the generous stipulations and multi-stage determination process outlined in the Act, coupled with the increase in the global refugee population. Initially, if a refugee claimant proved that they met the criteria for Convention refugee, they were granted permanent resident status. After obtaining

\footnotetext{
${ }^{27}$ Kelley \& Trebilcock, The Making of the Mosaic: A History of Canadian Immigration Policy, 381.

${ }^{28}$ Citizenship and Immigration Canada, "Archived- Forging Our Legacy: Canadian Citizenship and Immigration, 1900-1977," last modified July 01, 2006, accessed July $1^{\text {st }}, 2013$, http://www.cic.gc.ca/english/resources/publications/legacy/chap-6.asp.

${ }^{29}$ Martin Jones and Sasha Baglay, "Canadian Refugee Policy,” In Refugee Law, 10-11 (Toronto: Irwin Law, 2007).

${ }^{30}$ Economic Council of Canada, Economic and Social Impacts of Immigration, ed. Neil Swan, et al. (Ottawa: The Council, 1991).

${ }^{31}$ Kelley \& Trebilcock, The Making of the Mosaic: A History of Canadian Immigration Policy, 402.
} 
refugee status in Canada, an individual applied as a landed immigrant and subsequently could sponsor eligible family members to migrate to Canada within a few months. This is a crucial aspect of the policy, making Canada such a desirable destination for asylum seekers and potentially terrorist organizations, as they are able to sponsor other members of their organization through the refugee system. ${ }^{32}$ However, most claimants were found to be inadmissible upon presentation to an immigration officer as many claims were simply unfounded. ${ }^{33}$ Ineligible claims were sent to an immigration inquiry to determine whether or not they should be deported. For a redetermination of their claim, rejected claimants could apply to the Immigration Appeal Board (IAB). Subsequently, rejected applicants by the IAB could be appealed through the Federal Court. As a result, numerous asylum seekers came to Canada with bogus claims, having intentions to take advantage of the slow administrative procedures and to stay in the country without a departure order.

Consequently, by 1986 a backlog of 18000 cases developed as the system was created to deal with a small number of claims, whereby the government could not process claims fast enough. ${ }^{34}$ Between 1990 and 1999, Canada's refugee determination rate was $61.8 \%$. This is staggering when compared to other major destination countries including Australia, the United Kingdom, France, and the United States, none of which hit a $50 \%$ acceptance rate. ${ }^{35}$ As a result, this determination system was deemed one of the most (if not the most) open humanitarian

\footnotetext{
${ }^{32}$ Martin Collacott, Terrorism, Refugees and Homeland Security, (National Library of Canada Cataloguing in Publication Data, 2002), accessed June 12, 2013, http://www.immigrationwatchcanada.org/wp content/uploads/2010/11/rmc_collacott_15mar.pdf, 12.

${ }^{33}$ Manuel Garcia Griego, "Canada: Flexibility and Control in Immigration and Refugee Policy." In Controlling Immigration: A Global Perspective, ed. Cornelius, Wayne A., Philip L. Martin, and James Frank Hollifield, 127 (Stanford, California: Stanford University Press, 1994).

${ }^{34}$ Griego, "Canada: Flexibility and Control in Immigration and Refugee Policy," 127.

${ }^{35}$ United Nations High Commissioner for Refugees (UNHCR), Refugees and Others of Concern to UNHCR, 1999 Statistical Overview, (Geneva: 2000), accessed July 18, 2013, http://www.unhcr.org/3ae6bc834.pdf, 119
} 
refugee policies in the world, with more active international terrorist groups than any other country in the world (apart from the USA). ${ }^{36}$

Policy development is important, as it regulates who comes into the country and attempts to remedy backlogs (as seen above). More importantly, it also guards against the threat of terrorism. Terrorism in connection with Canadian migration began well before 9/11. During the 1960s and 1970s, a substantial increase in migrants and asylum seekers from the global south to the global north was instigated by disputes in the global south. Disputes abroad were reflected in a few areas of Canada including the Arab-Israeli dispute, and nationalist tensions in Yugoslavia, yet these disputes were not seen as imminent threats to Canadian national security. ${ }^{37}$ Arguably, international terrorism was not a major concern of the Canadian government until Sikh extremism began to develop in Canada during the 1980s. The Babbar Khalsa Society-one of India's largest terrorist organizations-was operating in Canada as a registered charity, supporting hatred against Hindus. This organization is said to have sparked the Canadian government's concern in international terrorism, establishing the Canadian Security Intelligence Service (CSIS) in $1984 .{ }^{38}$ On August 17, 1984, CSIS launched its first large scale terrorism investigation, targeting Sikh extremism. ${ }^{39}$ CSIS investigations warned of a possible attack on Air India, but unfortunately could not act in time to prevent the attacks. Before the World Trade Center bombings, the Air India attack on June 23, 1985 was considered the worst terrorist attack

\footnotetext{
${ }^{36}$ Collacott, Terrorism, Refugees and Homeland Security, 11. See also, Rhoda Howard, "Contemporary Canadian Public Policy: A Critical Assessment," Canadian Public Policy, 6, no. 2 (1980): 363, and Brett Story, "Politics as Usual: The Criminalization of Asylum Seekers in the United States." (Unpublished master thesis), University of Oxford, 2005), 2, accessed July 7, 2013, http://www.rsc.ox.ac.uk/publications/working-papersfolder_contents/RSCworkingpaper26.pdf.

${ }^{37}$ Bell Stewart, Cold Terror: How Canada Nurtures and Exports Terrorism Around the World, (Toronto: John Wiley \& Sons Canada Ltd., 2004), 5.

${ }^{38}$ Previously, national security was managed by the Royal Canadian Mounted Police (RCMP), as opposed to a separate agency dedicated to only security.

${ }^{39}$ Bell, Cold Terror: How Canada Nurtures and Exports Terrorism Around the World, 12.
} 
of modern time killing 329 people, including 154 Canadians. ${ }^{40}$ The mastermind behind the attacks was Talwinder Singh Parmar. Parmar was the founder of the Canadian branch of the Babbar Khalsa. Parmar was accused of six murders in India, however in immigrating to Canada, Canadian authorities refused to extradite him to Indian officials. More importantly, it took fifteen years to lay charges and properly accuse those responsible for the attacks. According to journalist Stewart Bell, "the failure to bring to justice the terrorists behind such a high profile attack within a reasonable time frame cemented Canada's international reputation as safe haven [...] [where] attacks [...] were not isolated incidents, but rather the opening shots of a new era that would see the world's major ethnic, religious and political conflicts spill across Canada's borders." 41

This migration "spill" described by Bell is evidenced with the refugee migration of Sri Lankans beginning in 1986, compounding Canada's increasing familiarity with terrorist groups coming into Canada through the immigration (refugee) system. Although Bell's book was written in 2004, a time when Tamil terrorist activity had decreased in Sri Lanka, the historical example provided depicts the inefficiency and leniency of the Canadian system. Fighting between the Liberation Tigers of Tamil Eelam (LTTE) and the Sinhalese in Sri Lanka caused a migration of Tamils to Europe and especially Canada, whose refugee laws were more lax compared to its international counterparts. Because of an accumulating claims backlog, refugee producing countries, including Sri Lanka, had claims expedited. Specifically "young Tamil males aged 10- 40 or 45 from the north and east and young Tamil females aged 13 to 30," received expedited claims in Canada. Many individuals of the LTTE fit this demographic.

\footnotetext{
${ }^{40}$ Anti-Defamation League, “Canada and Terrorism,” last modified January 2004, accessed July 8, 2013 , http://archive.adl.org/terror/tu/tu_0401_canada.asp

${ }^{41}$ Bell, Cold Terror: How Canada Nurtures and Exports Terrorism Around the World, 20.
} 
Outside Sri Lanka, Canada is now home to the largest population of Tamils. ${ }^{42}$ More importantly, the Tamil Tiger supporters have been able to operate freely in Canada, establishing a complex fundraising network, sending money back to support the Tigers' warfare in Sri Lanka. In fact, the RCMP and CSIS warned the Liberal government (at the time) that there were fifty active terrorist organizations in Canada, particularly the Federation of Associations of Canadian Tamils (FACT), a front organization for the LTTE. ${ }^{43}$ Regardless of this warning, former Prime Minister Paul Martin and former Minister of International Cooperation Maria Minna attended a fundraising dinner hosted by FACT. Martin's actions were unexplainable and embarrassing, to say the least. As stated perfectly by Stoffman, Martin deliberately performed a "disservice to his country." $" 44$

Terrorist entry into Canada through the refugee determination system continued into the 1990s. One must not forget the case of Ahmed Ressam: the terrorist who attempted to blow up the Los Angeles International Airport by smuggling 60 kilograms of explosives across the USCanada border. Ressam was a Canadian refugee claimant, having come to Canada in 1994 using a fake French passport. ${ }^{45}$ He claimed refugee status after officials realized his passport was fraudulent. Ressam then resided in Montreal, where he was receiving welfare. In 1995, he was denied refugee status after he failed to appear for his hearing. Even his appeal was denied. Subsequently, he managed to remain in the country, with a criminal record, even after there was a warrant for his arrest. What is more infuriating is that Ressam stole documents which were

\footnotetext{
${ }^{42}$ Ibid., 32-33.

${ }^{43}$ Stoffman, Who Gets In: What's wrong with Canada's Immigration Program and how to fix it, 18-19. See also, Collacott, Terrorism, Refugees and Homeland Security, 2, and Michael King, Ali Mohamed, and Farah AwOsman. Terror in the Peaceable Kingdom: Understanding and Addressing Violent Extremism in Canada. Edited by Frum Linda, and Daveed Gartenstein-Ross. Washington, D.C.: FDD Press, 2013, 42.

${ }^{44}$ Stoffman, Who Gets In: What's wrong with Canada's Immigration Program and how to fix it, 19.

45 PBS, “Ahmed Ressam's Millennium Plot," last modified 2013, accessed August $1^{\text {st }}, 2013$, http://www.pbs.org/wgbh/pages/frontline/shows/trail/inside/cron.html. See also, Stoffman, Who Gets In: What's wrong with Canada's Immigration Program and how to fix it, 9, and Collacott, Terrorism, Refugees and Homeland Security, 11.
} 
used to obtain a Canadian passport. Using this passport, he was able to travel to Afghanistan to receive terrorist training and instruction on how to assemble explosives, in camps funded by Osama bin Laden. He re-entered Canada using his fake Canadian passport, under the name of Benni Norris. Through this fake identification, he was also able to obtain a drivers license and an apartment lease. On the morning of December $14^{\text {th }}$, Ressam bypassed Canadian officials and boarded his car (filled with explosives) onto a ferry from Victoria, British Columbia to Port Angeles, Washington. Upon arriving in the US, the explosives were discovered and he was arrested. He was later convicted of conspiracy to commit an international terrorist act, explosives smuggling, and lying to customs officials, resulting in 130 years in prison. ${ }^{46}$ Ressam's purpose in coming to Canada was not for refuge, but was to gain entry in Canadian society for the purpose of terrorism against the Americans. A very flawed Canadian refugee system or the unwillingness of Canadian officials to remedy the problem either by detaining or deporting him not only allowed Ressam to stay in the country but permitted him to facilitate a terror plot that could have killed thousands.

Finally, the case of Mahmoud Mohammad Issa Mohammad, a member of the Popular Front for the Liberation of Palestine (PFLP), also perfectly symbolizes the deficiencies and openness of the system while displaying the blatant abuse by asylum seekers and entrance of terror threats into the country. In 1968 Mohammad took part in El Al Airline hijacking in Greece. The PFLP demanded his release from a Greece jail, as part of a hostage exchange, after committing another hijacking. ${ }^{47}$ He fled to Canada where he failed to disclose to Canadian authorities his criminal past. Canadian authorities were also deficient in uncovering this

\footnotetext{
${ }^{46}$ PBS, “Ahmed Ressam's Millennium Plot," last modified 2013, accessed August 1 $1^{\text {st }}, 2013$, http://www.pbs.org/wgbh/pages/frontline/shows/trail/inside/cron.html

${ }^{47}$ Stoffman, Who Gets In: What's wrong with Canada's Immigration Program and how to fix it, 172-173. See also, Collacott, Terrorism, Refugees and Homeland Security, 6.
} 
information. When it was revealed that he was in fact a terrorist, Canadian immigration officials ordered his deportation in $1988 .{ }^{48}$ Mohammed claimed to be tortured if returned back to Lebanon and launched over forty appeals, delaying his stay in Canada. On May 11, 2013, Mohammed was finally deported back to Lebanon, but not before costing taxpayers $\$ 3$ million in addition to welfare and other financial expenses, ${ }^{49}$ as well as jeopardizing the security of Canadians for nearly three decades.

This case is significant as it is encompassing of the numerous problems reflected historically in the Canadian refugee system. It presents a blatant mockery and abuse of the system by terrorists. Not only was Mohammed able to live freely in Canadian society, he was able to stage twenty six years worth of refugee appeals. The obvious question is why did it take almost three decades to deport a single individual? How could the Canadian government and all of its forces be consistently deceived by one person, who was a proven terrorist? The refugee system was formulated in such a way that Mohammed was permitted by law to launch numerous appeals which simply lengthened his stay in Canada. Moreover, precious resources were spent on Mohammad's pointless appeals, instead of being used to help others with legitimate claims.

Mohammed, Ressam, and the LTTE have challenged the integrity of Canada's refugee system and its ability to facilitate legitimate refugee migration. This is not a definitive list of terrorist threats to Canada, but these examples are certainly symptomatic of the problems within the refugee system. These cases display the government's failure to acknowledge the security risks that Canadians citizens were exposed to as a result of the problems within the refugee determination system. Moreover, even though the cases about Ressam and Mohommad might appear to be "exaggerated," they are an accurate representation of the cases within the refugee

\footnotetext{
${ }^{48}$ Bell, Cold Terror: How Canada Nurtures and Exports Terrorism Around the World, 81.

${ }^{49}$ Brian Lilley, "We can't even kick out the terrorists," Toronto Sun, sec. Opinion, March 11, 2011, accessed July 10, 2013, http://www.torontosun.com/comment/columnists/brian_lilley/2011/03/10/17575056.html
} 
system. The similarities between these two cases include asylum seekers making bogus claims to enter Canada (for reasons other than those in the1951 UN Refugee Convention Relating to the Status of Refugees), and proceed to use the appeal process to lengthen their stay in Canada. These similarities extend to more recent (or "normalized") cases, including Roma from Hungary. Canada has witnessed a spike in refugee claims from this population. ${ }^{50}$ Interestingly, Hungary is member-country of the European Union meaning members can live and work freely in member states. Leaving the Europe for Canada is questionable, especially because Europe (and its member states) is relatively safe and respects human rights. According to former Immigration Minister Jason Kenney, the majority of Hungarian refugee claims are rejected by the IRB, withdrawn, or abandoned. The Roma do not display a sensational or dramatic example such as Ressam or Mohammed, but nonetheless similar abuse has occurred. Overall, the trustworthiness of our system is in question. What becomes more troubling is when abusers of the system are individuals who can also harm the safety of Canadians and the global community. Internationally, Canada's refugee system was given a bad reputation, being deemed "lax" or a "safe haven for terrorists." At the same time, it also gave the impression to other terrorists or criminals that they might be able to infiltrate the system and enter Canada illegally. As refugee policy developed during this period, problems with the system became increasingly evident.

Specifically, landmark court verdicts and the resulting policy enacted during the 1980s ultimately influenced refugee policy and have considerable challenges and implications for today's system. However, the enactment of new policies and the subsequent expansion of rights afforded to refugees were primarily made possible through the Charter. During the 1980s, the

\footnotetext{
${ }^{50}$ Katheryn, Carlson, "Record number of Hungarian asylum-seekers landing on Canada's doorstep," National Post, November 4, 2011, accessed August 27, 2013, http://news.nationalpost.com/2011/11/04/record-number-ofhungarian-asylum-seekers-landing-on-canadas-doorstep/. See also, CBC News, "Kenney names 27 countries as 'safe' in refugee claim dealings," last modified 14, 2013, accessed August 27, 2013, http://www.cbc.ca/news/canada/story/2012/12/14/pol-immigration-safe-third-countries-dco-kenney.html.
} 
enshrinement of the Charter into the Constitution by Pierre Eliot Trudeau was seen as a mechanism that would enable individuals to oppose the state by challenging laws through judicial review. ${ }^{51}$ The pre-Charter Court adopted a modest view of its powers of judicial review in relation to the elected legislature, only occasionally striking down laws on jurisdictional reasoning, but shying away from reviewing the substance of the laws. ${ }^{52}$ The implementation of the Charter fueled the growth of judicial review. ${ }^{53}$ As Raymond Bazowski has noted, with the adoption of the Constitution Act 1982 and the enshrinement of the Charter in the same year, the issue regarding the status of judicial review in Canada was in part resolved by "explicitly recognizing the principle of constitutional supremacy."54 Specifically, s. 52(1) of the Constitution Act 1982 and s. 24(1) of the Charter established constitutional supremacy where the limits on political powers are enforced by judicial review of statutes and improper conduct of government officials. ${ }^{55}$ These two pieces of legislation were instituted at a perfect time in relation to refugees' rights. In combination with the Immigration Act, the Constitution Act of 1982 and the enshrinement of the Charter allowed refugee claimants to challenge pieces of the Act, through seeking judicial review. It was during the 1980s that refugee claims forever changed the Canadian legal infrastructure, creating unassailable pieces of legislation that are now embedded in the Charter and applicable in numerous refugee determination cases today.

There are various refugee cases challenging the Charter including Suresh v. Canada and Ahani v. Canada. Arguably the most significant refugee case challenging the Charter is Singh $v$

\footnotetext{
${ }^{51}$ Sébastien Lebel-Grenier, "The Charter and Legitimization and Judicial Activism," in Judicial Power and Canadian Democracy, P. Howe and P. Rusell, Ed., (McGill-Queen's University Press: Montreal. 2001 ), 95.

${ }^{52}$ Raymond Bazowski, "For the Love of Justice? Judicial Review in Canada and the United States." In Constitutional Politics in Canada and the United States. Ed. S. L. Newman. (New York: State University of New York Press, 2004), 228.

${ }^{53}$ Christopher P. Manfredi, Judicial Power and the Charter: Canada and the Paradox of Liberal Constitutionalism $2^{\text {nd }}$ ed. Toronto: Oxford University Press. 200: viv.

${ }_{54}$ Bazowski, "For the Love of Justice? Judicial Review in Canada and the United States." 228.

${ }^{55}$ Manfredi, Judicial Power and the Charter: Canada and the Paradox of Liberal Constitutionalism $2^{\text {nd }}$ ed., 21.
} 
Minister of Employment and Immigration. ${ }^{56}$ In this case, the minister had rejected the refugee claims of seven failed claimants, who were also denied a hearing at the IAB as well as the Federal Court. Singh challenged the constitutionality of s.7 of the Charter: "Everyone has the right to life, liberty and security of the person and not to be denied thereof expect in accordance with the principles of fundamental justice." Singh resulted in a landmark decision regarding procedural fairness and the status of refugee rights in Canada. The majority ruled that everyone present on Canadian soil is granted rights under the Charter. The Supreme Court ruled that the term "Everyone" in s.7 "is sufficiently broad to include [non-citizens] in its compass and ... every human being who is physically present in Canada and by virtue of such presence amenable to Canadian law. ${ }^{, 57}$ In effect, the court ruled that even though these individuals were not Canadian citizens and entered Canada illegally, they were still entitled to all basic rights and freedoms enjoyed by Canadian citizens. This ruling was certainly a victory for refugee advocates and is beneficial to refugees as they are stateless persons and cannot be protected by the "rights" (if any) from their country of origin. The concept of reciprocity is enforced with the Singh decision: "if asylum seekers are to be subject to the full force of the Canadian law, then they are logically entitled to benefit from Canadian standards of respect for human dignity. ${ }^{, 58}$ However, what rights advocates fail to acknowledge is the effect this ruling has on the value of Canadian citizenship. The ruling challenges the value of Canadian citizenship as there is no differentiation from the rights afforded to Canadians and the rights afforded to illegal migrants physically present in Canada. In effect, an individual who is not Canadian is enjoying the same protections

\footnotetext{
${ }^{56}$ Singh v. Canada (Minister of Employment and Immigration) [1985] S.C.R. 177. Hereinafter referred to as Singh.

${ }^{57}$ Ibid., 31, para 35.

${ }^{58}$ Francois Crépeau and Delphine Nakache, "Controlling Irregular Migration in Canada: Reconciling Security Concerns with Human Rights Protection,” IRPP Choices, 12, no. 1 (2006): 6.
} 
as Canadians. ${ }^{59}$ As stated by former Deputy Minister of Immigration John Manion, the Singh decision "destroyed any immigration control, and made Canada the laughing stock of the rest of the world and the destination of too many footloose criminals, terrorists and social parasites." In an age of increasing international migration and blurred distinction of boundaries between international communities, the question of inherent rights with respect to citizenship is problematized. Some would argue that simply by virtue of being Canadian, Canadians should have distinguished rights from illegal entrants. There is no debating that everyone should always be given absolute rights. For example, everyone should enjoy freedom from torture or other cruel and inhuman treatment as well as freedom from slavery. Additionally everyone should have recognition before the law. Under no circumstances can these rights be violated or even limited. However, aside from absolute rights, Canadians should have distinguished rights from illegal entrants, by virtue of being Canadian, where rights encapsulate the benefits of Canadian citizenship.

In addition, the question in Singh was whether or not a fair hearing requires the affected persons to know the case against them and be permitted to respond to that case. In Singh, the appellants had to establish that the minister's case was wrong, without any knowledge of the minister's case. The Court noted that the issue with the refugee determination scheme was "the inadequacy of the opportunity the scheme provides for a refugee claimant to state his case and know the case he has to meet". ${ }^{61}$ The government argued that costs and delays throughout the system would result because of the ruling, but the court stated that "the guarantees of the Charter would be illusory if they could be ignored because it was administratively convenient to do so." ${ }^{, 62}$

\footnotetext{
${ }^{59}$ Collacott, “Canada's Inadequate Response to Terrorism: the Need for Policy Reform, ” 39.

${ }^{60}$ Ibid., 40.

${ }^{61}$ Singh v. Canada [1985] at 45 para 60.

${ }^{62}$ Ibid., 49, para 70.
} 
As a result of this ruling, the Refugee Reform Bill created the Immigration and Refugee Board (IRB). The IRB is responsible for providing an oral hearing on refugee claims and appeals on sponsorship and removal cases. Refugees are now entitled to an oral hearing where they are able to hear the government's case for refugee refusal, and have an opportunity to respond to it. As will be seen, this ruling allows any individual to make a refugee claim and have complete access to Canada's appeal systems.

Collacott believes that a simpler hearing should be conducted by an immigration officer as opposed to a formal hearing by the Immigration and Refugee Board. ${ }^{63}$ However, this disregards the numerous responsibilities officers already presume. More importantly, one questions the competency of officers to actually give a fair and objective hearing to a claimant. An oral hearing by a separate branch of the refugee system is necessary considering the extraordinary circumstances of a refugee claimant. In claiming refuge, it is assumed an individual has a well-founded fear of persecution. By virtue of this fear and the dire circumstances that one might encounter in their country of origin, a route to appeal is essential to give the claimant one last opportunity to prove their case and prove that officials erred in their decisions. Nonetheless, the results from Singh will be forever entrenched within Canada's refugee policies, paving a path for an arguably more open system. Likewise, legislation originating from the Singh verdict becomes especially important when dealing with a more security caution era.

By the end of the 1990s, national security became a crucial focus of policy as the regular arrival of refugees was seen as excessive and claimants were viewed as individuals abusing the

\footnotetext{
${ }^{63}$ Collacott, "Canada's Inadequate Response to Terrorism: the Need for Policy Reform," 40-41. See also, Stoffman, Who Gets in: What's Wrong with Canada's with Canada's Immigration System and how to fix it, 85.
} 
system. ${ }^{64}$ Consequently, Bill C-11, the IRPA, received Royal Assent on November $1{ }^{\text {st }} 2001$, with the intention to accelerate the determination process as well as tighten Canada's refugee system. As stated by former Citizenship and Immigration Minister Elinor Caplan, "By saying 'No' more quickly to people who would abuse our rules, we are able to say 'Yes' more often to the immigrants and refugees Canada will need to grow and prosper in the years ahead." ${ }^{, 65}$ However, Caplan's seemingly hard stance towards immigration was met with much criticism, especially by special interest groups including the Canadian Council of Refugees, Canadian Bar Association, and Amnesty International. ${ }^{66}$ These organizations mainly criticised Bill C-11 for being too stringent on refugee claimants, maintaining an enforcement mentality, and giving draconian powers to the state and immigration officials. Resultantly, several segments of Bill C-11 were amended. As will be seen below, attempted changes to significantly decrease the vulnerability of the refugee system were hardly adapted.

Upon arrival in Canada, asylum seekers make a claim for refuge to an official of Canadian Border Services Agency at port of entry. A preliminary interview is conducted and a Personal Information Form is completed. The eligibility of the claimant must be made within three days of the claim. There are several restrictions which ban a claimant from being referred to the Refugee Protection Division (RPD). Namely, a claimant who already has a pending refugee claim or was previously determined to be ineligible is not eligible for referral. Moreover, if another country already recognizes the claimant as a refugee, they are protected and cannot apply for referral in Canada. On the same note, if a claimant comes to Canada indirectly or

\footnotetext{
${ }^{64}$ Sandy Irvine, "Canadian Refugee Policy: Understanding the role of international bureaucratic networks in domestic paradigm change," in Policy Paradigms, Transnationalism, and Domestic Politics, edited by Grace Darlene Skogstad, Toronto: University of Toronto Press, 2011, 7.

65 "Canada: C-11, Professionals, Mexicans," Migration News, 8, no. 6 (2001), accessed June 6, 2013 , http://migration.ucdavis.edu/mn/more.php?id=2384_0_2_0

${ }^{66}$ Kislenko, "Guarding the Border: Intelligence and Law Enforcement in Canada's Immigration System,” 321.
} 
directly from a "safe third country," they are ineligible for referral, simply because the country they were previously was safe enough to claim refuge. Lastly, claimants are inadmissible on grounds of security. Some examples include claimants who participated in terrorism, espionage, subversion or organized criminality. Likewise, those who violated human or international rights or were involved in crimes against humanity are unable to apply to the RPD ${ }^{67}$ Nonetheless, even if asylum seekers are unable to access the RPD, they still have access to the Federal Court to appeal the officer's decision.

There are several scenarios in which officers will detain an asylum seeker. First off, if there are reasonable grounds to suspect that an individual is a threat to national security or is suspected of violating human or international rights, the claimant will be detained. Similarly, if the officer has reasonable grounds to suspect that the asylum seeker is inadmissible on grounds of security, specifically if they are a danger to the public, then they will be detained. ${ }^{68}$ Additionally, a claimant will be detained if their examination (as to whether or not they are a security threat) must be complete or if the officer is unsatisfied with the identity of the foreign national in the course of any procedure under the IRPA. A claimant will also be detained if it is determined that they are unlikely to appear for examination, an admissibility hearing, or removal from Canada. Detainment is an essential tool needed to protect the security of people already in Canada. However, detention denies an individual of their liberty and must be used only when all other "reasonable alternatives" have been exhausted. ${ }^{69}$

If a claim for refuge is accepted, refugee claimants are referred to the RPD, where a formal hearing is held to determine if their claim is legitimate and deserving of protection from

\footnotetext{
${ }^{67}$ Citizenship and Immigration Canada, "PP 1 Processing claims for refugee protection in Canada," last modified February 17, 2012, accessed July 4, 2013, http://www.cic.gc.ca/english/resources/manuals/pp/pp01-eng.pdf, 11-13.

${ }^{68}$ Citizenship and Immigration Canada, "ENF 20: Detention," last modified Sept. 26, 2007, http://www.cic.gc.ca/english/resources/manuals/enf/enf20-eng.pdf.

${ }^{69}$ Ibid., 6-7.
} 
Canada. If a claimant is determined legitimate, refugee status is granted. However, if the claim is rejected, claimants are able to file an application for judicial review by the Federal Court of Canada. If the Federal Court determines the claim to be illegitimate, the asylum seeker receives a removal. But, even after a negative verdict by the Federal Courts, the claimant can ask for a preremoval risk assessment (PRRA) to be completed. ${ }^{70}$ PRRA determines the risk level in country of origin and whether or not the country is safe for the claimant to be deported back to. Additionally, it allows the applicant to present new evidence in the case but he or she cannot argue that the original decision was wrong. As a PRRA is being completed, the failed claimant is also permitted to apply to stay in Canada on humanitarian and compassionate grounds (H\&C). Citizenship and Immigration Canada (CIC) decides whether a failed claimant should be allowed to stay in Canada via $\mathrm{H} \& \mathrm{C}$ by assessing how long the person is in Canada, general family ties to Canada, the best interests of any children involved, and what could happen to the claimant if the request is not granted. ${ }^{71}$ After the completion of a PRRA, if the country of origin is determined to be safe for the claimant to return, a removal is ordered.

A removal is issued after all the avenues of appeal have been exhausted. Officers of CBSA are responsible for removals, which take three forms. Refugee claimants automatically receive a "departure order" when applying for refugee status, however the order is only enforceable once a determination is made as to whether or not refugee status is awarded. Once it is determined that claimants are not applicable for refugee status, they have thirty days to voluntarily leave the country. Failure to comply with the thirty day timeline will result in the departure order turning into a "deportation order." With a deportation order, one is forever

\footnotetext{
${ }^{70}$ Citizenship and Immigration Canada, "PP 1 Processing claims for refugee protection in Canada," last modified February 17, 2012, accessed July 4, 2013 from www.cic.gc.ca/english/resources/manuals/pp/pp01-eng.pdf, 38.

${ }^{71}$ Citizenship and Immigration Canada, "Humanitarian and Compassionate Grounds," last modified October 26, 2012, accessed July 18, 2013, http://www.cic.gc.ca/english/refugees/inside/h-and-c.asp
} 
banned from Canada unless written permission is obtained from CBSA. Finally, asylum seekers who have an "exclusion order" are ban from Canada for a year and can only return with written permission from CBSA. ${ }^{72}$ As exemplified, Canada's refugee determination system is a very complex process with numerous steps.

Regardless, throughout the entire determination process including the assessment of claims, appeals, and deportation orders, the rights of asylum seekers must be maintained to uphold a creditable and legitimate system. However, the IRPA is a contested piece of legislation especially by refugee and human rights advocates. They take issue with several segments of the IRPA. As stated above, the IRPA deems asylum seekers inadmissible to Canada on security grounds if they are suspected to be members of a terrorist organization or involved in terrorist activities. This in itself is problematic for human rights advocates. According to Paul Hoffman, Crépeau and Nakache, Shamsul Haque, Faisal Bhabha, Wesley Pue, and Sharryn Aiken the controversy lies with the definition of "terrorism" or "terrorist activity." Refugee advocates criticize the IRPA's definition of terrorism (as defined above by the Criminal Code) for being too broad as to encompass individuals who have committed minor crimes, belonging to a terrorist organization in which the individual was unaware of such activities, or belonged to an political activist group wrongly mistaken for a terrorist organization. ${ }^{73}$ As a result, rights advocates argue that the "one size fits all" definition of terrorism allows for a greater number of asylum seekers to fall within its ambit. ${ }^{74}$ Consequently, a broad definition has numerous consequences for

\footnotetext{
72 Canadian Border Services Agency, "Fact Sheet- Removals," last modified January 08, 2013, accessed August 11, 2013, http://www.cbsa-asfc.gc.ca/media/facts-faits/051-eng.html

${ }^{73}$ Kelley \& Trebilcock, The Making of the Mosaic: A History of Canadian Immigration Policy, 442. See also, Crépeau and Nakache, "Controlling Irregular Migration in Canada: Reconciling Security Concerns with Human Rights Protection," 22.

${ }^{74}$ Wesley Pue, "The War on Terror: Constitutional Governance in a State of Permanent Warfare?," Osgoode Hall Law Journal, no. 41 (2003): 271. See also, Bhabha, "Tracking 'Terrorists' or Solidifying Tereotypes? Canada's AntiTerrorism Act in Light of the Charter's Equality Guarantee," 111.
} 
claimants trying to come into Canada as they might fit within the scope of "terrorism." More people are being brought within this definition's scope.

However, having a universal or specific definition of terrorism is elusive. Indeed, American Supreme Court Judge Potter Stewart even remarked that it is difficult to define but "one knows when he or she sees it." 75 Human rights advocates disregard that the definition must be broad enough in nature to capture the underlying motivation of terrorism and terrorist activity. Terrorism as defined by the Criminal Code, serves to encapsulate the very multi-facet nature of the crime. A broader definition allows Canadian officials the necessary tools to identify terrorism and exclude claimants on these grounds. The motivational element of the attacks is what drastically differentiates terrorist activity from an average protest or illegal strike. Terrorism is a very irregular mode of conflict, including an ideological dimension in which terror is inflicted upon a civilian population or government causing a considerable harm (or apprehension of harm) to seek specific goals. The effects of terrorism stretch "beyond the circumstance of isolated or singular crimes. ${ }^{, 76}$ For example, blocking a bridge in protest or staging an illegal strike are not acts of terror because they are not motivated by terror. However, if said examples somehow have the potential to cause "death, bodily harm, endangers life, or threatens public health and safety," then actions would constitute terrorism. ${ }^{77}$ Terrorism is an assault upon a state's democracy and its people, which differs drastically from easily identifying other types of crimes (e.g. a robbery or drug dealing). However, rights advocates downplay its particularities in arguing for a narrower definition.

\footnotetext{
${ }^{75}$ David Jenkins, “In Support of Canada's Anti-Terrorism Act: A Comparison of Canadian, British, and American Anti-Terrorism Law,” Saskatchewan Law Review, 66 (2003): 421.

${ }^{76}$ Ibid., 424.

${ }^{77}$ Ibid., 425.
} 
Additionally, in the event that an individual is not permitted into Canada because of participation in a terrorist group, it is believed by refugee advocates that the burden of proof (the party required to prove either innocence or guilt of the defendant) should rest on the state. Considering the broad definition of terrorism, Crépeau and Nakache argue that one's affiliation with a terrorist organization should be proven beyond a reasonable doubt. ${ }^{78}$ Proof beyond a reasonable doubt, established by the Supreme Court of Canada in R. v. Lifchus, "does not involve proof to an absolute certainty; it is not proof beyond any doubt nor is it an imaginary or frivolous doubt; and more is required than proof that the accused is probably guilty." 79 This standard (which refugee advocates wish to invoke) implies that the state must be $100 \%$ certain that an individual is a member of a terrorist organization.

However, the burden of proof should not rest with government, but with refugee claimants. Refugee claimants have not been formally charged under the Criminal Code for committing a terrorist offence. Thus, claimants are not automatically afforded the protection of having the government prove beyond a reasonable doubt that they are associated with a terrorist organization (as argued by refugee advocates). Proof beyond a reasonable doubt is reserved solely for criminal accusations. Moreover, in all situations when an individual is making a refugee claim, it the responsibility of the claimant to prove to the government how they are in fact refugees. If a claimant is potentially inadmissible on security grounds (including association with a terrorist organization), proving that he or she is not a member of a terrorist organization is already a mandatory credential of gaining admission into Canada and should not be changed to have the burden of proof rest on the government.

\footnotetext{
${ }^{78}$ Crépeau and Nakache, "Controlling Irregular Migration in Canada: Reconciling Security Concerns with Human Rights Protection,” 22.

${ }^{79}$ R.v. Lifchus, [1997] 3 S.C.R. 320 at para 36.
} 
Refugees must prove that they are not associated with a terrorist organization, however the degree of proof is lessened by allowing them to prove their innocence through a balance of probabilities. A balance of probabilities is an appropriate degree of proof, especially for the refugee, as it requires a lesser degree of proof when compared to "beyond a reasonable doubt." Proof beyond a reasonable doubt would require a $100 \%$ guarantee (without doubt) that the individual is in fact not associated with a terrorist group. It would be extremely difficult for a claimant to guarantee a court that they are not part of a terrorist organization. With a balance of probabilities, the onus rests on the claimant to prove that he or she is not likely to be part of a criminal association. For example, if the ruling is $51 \%$ in favour of the claimant, then he or she has successfully proven that they are not part of a terrorist organization. Refugee advocates do not realize that the Canadian state has struck a fair balance in placing the burden of proof on the refugee, and lessening the degree of proof in allowing claimants to prove a balance of probabilities as opposed to beyond a reasonable doubt.

Along with the broad definition of terrorism, refugee advocates take issue with additional segments of the IRPA. Specifically, immigration officers were granted expanded powers to arrest and detain non-citizens upon entry to Canada; the government increased the scope in which refugee claimants were able to be detained without warrant in situations where "an officer is not satisfied with a person's identity." ${ }^{\prime 80}$ The vagueness and broadness entwined within the definition of terrorism gives little guidance to governmental personnel. For example, what is the threshold for "serious" damage? New powers under the IRPA coupled with the expanded definition of terrorism create a hostile climate for asylum seekers. As a result, too much discretion is given to

\footnotetext{
${ }^{80}$ Sharryn J. Aiken, "National Security and Canadian Immigration: Deconstructing the Discourse of Trade-Offs." In The Complex Dynamics of International Migration, edited by Francios Crepeau, 84, Montreal: Presses de l'Universite de Montreal, 2009.
} 
those applying the law, ${ }^{81}$ which can also lead to different and potentially unfair applications of the law in various situations. Consequently, legitimate claimants seeking refuge from political persecution and trying to implement democracy in their countries are being denied refugee status simply because their acts fall under the broad scope of "terrorism." A greater number of people can fall within boundaries of a terrorist or engaging in terrorism. However, this being said, discretion can also work in the opposite direction. In using discretion, officers also have the option of acting very liberally in not considering certain actions (or group affiliations) as terrorist in nature. As a result, there is the possibility that more individuals (and more terror threats) can be let into the country.

The definition of terrorism under the IRPA has far several consequences. If an individual is deemed a terrorist or had participated in a terrorist organization, Anti-Terrorism Act ${ }^{82}$ is invoked, whereby a claimant can be removed under a security certificate. It is beyond the scope of this paper to discuss the $A T A$ in detail. One must simply understand that a security certificate allows the removal of a claimant who was or is a terrorist as well as the removal of a claimant who had previous involvement with a terrorist organization or is currently involved with a terrorist organization. ${ }^{83}$

Specifically, Bhabha, Pue, and Aiken discuss the effects of IRPA and ATA on Muslims and Arab claimants. Aiken bluntly states that immigrants and Arab and Muslim refugees "remain the chief targets of Canada's national security agenda." ${ }^{, 84}$ Firstly, this claim derives specifically from The Council on American Islamic Relations Canada as well as two authors who write on racial profiling in Canada. In reviewing a one-sided contention, specifically deriving from the

\footnotetext{
${ }^{81}$ Pue, "The War on Terror: Constitutional Governance in a State of Permanent Warfare?" 274.

${ }^{82}$ Hereinafter referred to as the ATA.

${ }^{83}$ Elizabeth Liu, Centre for Constitutional Studies, "Security Certificates," last modified 2013, accessed August 1 st, 2013, http://www.law.ualberta.ca/centres/ccs/issues/securitycertificates.php

${ }^{84}$ Aiken, "National Security and Canadian Immigration: Deconstructing the Discourse of Trade-Offs," 174.
} 
Council on American Islamic Relations, Aiken presents claims derived from bias sources. The Council on American Islamic Relations may feel as if they are being targeted, or think that new laws might discriminate against them, but it does not inherently mean that laws are in fact discriminating against them. There is no statistical evidence provided by any of the authors in proving that Muslims are in fact the central security targets in Canada, particularly the percentage being detained relative to the detention of other nationalities, or how many Muslims were actually denied entry into Canada for denied refugee status. As a result, an assumption is being made as human rights advocates are actually intrinsically linking Muslims with the 9/11 attacks.

The argument continues in stating that stigmatization of Arab and Muslim individuals will cause discrimination on the basis of race, religion, colour, and ethnic or national origin resulting in equality rights violations. ${ }^{85}$ As a result of assuming that Arab and Muslim refugee claimants will be targeted at the border, a flawed conclusion results. Bhabha, Aiken, as well as Crépeau and Nakache believe that racial profiling has the potential to occur, thus violating a Charter right: the right of equality under the law. S. 15(1) of the Charter states that "every individual is equal before and under the law and has the right to the equal protection and equal benefit of the law without discrimination..." Furthermore, it is contended that non-citizen Muslims will be doubly discriminated against (compared to Muslims who are Canadian citizens) by virtue of being Muslim and non-citizens. ${ }^{86}$ The Charter states that everyone in Canada is subject to Canadian law as well as the rights and freedoms afforded by Canadian law. Arab and Muslim asylum seekers should not have their s. 15 equality rights violated simply by virtue of their race of religion. However, as summarized by Bhabha "the government [has] adopted

\footnotetext{
${ }^{85}$ Bhabha, "Tracking 'Terrorists' or Solidifying Tereotypes? Canada's Anti-Terrorism Act in Light of the Charter's Equality Guarantee?" 98.

${ }^{86}$ Ibid., 116.
} 
extreme measures that tear at the seams of the Charter protection and target communities and individuals who already sit on the fringe of the law's protection." ${ }^{, 87}$ What is problematic about this contention is that none of the authors cite cases in which s.15 rights were violated and where the court ruled in favour of the refugee for a violation of rights. Moreover, the IRPA has been in effect for approximately twelve years, and throughout this time-span, not one case was ruled a violation of equality rights under s.15. Without any tangible evidence to prove the violation of said right, this claim is dubious.

Overall, refugee and human rights advocates claim that Canada is engaging in nondemocratic practices, namely the violation of refugee rights. Canada preaches for equality, diversity and fairness however, "Meaningful equality implies protecting foreigners against human rights abuses to the same extent as citizens are protected." ${ }^{, 88}$ Most importantly, advocates believe provisions outlined in the IRPA, including the definition of terrorism and the discretion given to immigration officials proves detrimental to refugee claimants. The refugee determination system has the potential to exclude legitimate refugees through denying entry on actions falling under the definition of terrorism. Both Hoffman and Aiken conclude policy goals should maintain a balance between national security and human rights. However, this being said, arguments in favour of refugees are heavily weighted towards a refugee rights agenda and disregard the nature of terrorism and the degree of security and precaution need to be taken, especially in a post-9/11 society.

Moreover, advocates that claim the government engages in a complete violation of human rights are wrong. This has not been sufficiently proved by refugee advocates and moreover, Canada has laws making a "complete violation of rights" difficult to occur. Secondly,

\footnotetext{
${ }^{87}$ Ibid., 97.

${ }^{88}$ Crépeau and Nakache, "Controlling Irregular Migration in Canada: Reconciling Security Concerns with Human Rights Protection," 28.
} 
rights advocates have not at all acknowledged s.1 of the Charter which allows reasonable limits on the rights and freedoms provided in the Charter, so long as they are justifiable by law in a democratic society. S.1 does not allow for a limitless violation of rights, and this is certainly not what this paper argues for. However, when it is in the best interest of society, and specifically the nation, one's rights are subjected to justifiable limitations. A limitation of rights is lawful as per s.1 of the Charter, in the most minimally intrusive way possible. Additionally, what is not acknowledged by refugee advocates is the fundamental difference between a limiting of rights and a violation of rights. When one's rights are limited, they are limited lawfully under the Charter. However, a violation (as argued by refugee advocates) implies that a right is infringed upon and cannot be justified under S.1 of the Charter. Based on the above contentions, the government has upheld the rights of refugees and there has been no violation of human rights that have not been remedied by the SCC.

Rights advocates also contend that after the terror attacks of 9/11, migration flows have been conveyed as a security threat where the "link between immigration and hard forms of security became more concrete despite the economic importance of the global flow of people and ideas. ${ }^{\prime 89}$ Moreover, refugee advocates including Erin Kruger et al., and Robert Russo believe that the Canadian government has intrinsically linked refugee claimants to terrorism. Refugee claimants have been defined as the security threat with the potential to harm the nation state and safety of Canadians. ${ }^{90}$ As a result, conflating 'refugee claimant' with 'terrorist' allows the terrorist threat to become an "imported problem, encouraging a security mentality that seeks to

\footnotetext{
${ }^{89}$ Pamela Irving Jackson, and Roderick Parke, "Globalization and the Secularization of Immigration Policy: Competing Influences on Immigrant Integration Policy in Germany, France, Britain, and the United States," Human Architecture, 4, no. 3 (2006): 174.

${ }^{90}$ Robert M. Russo, "Security, Securitization and Human Capital: The New Wave of Canadian Immigration Laws," International Journal of Human and Social Sciences 3, no. 4 (2008): 300. See also, Erin Kruger, Marlene Mulder, and Bojan Korenic, "Canada after 11 September: Security Measures and "Preferred" Immigrants," Mediterranean Quarterly, 15, no. 4 (2004): 78.
} 
prevent and deter outsiders from entering Canada." ${ }^{.91}$ Specifically, what must be determined is how refugee advocates claim the refugee and terrorist have become associated and in some cases inseparably linked, establishing how the national security of Canada has begun to focus predominantly on refugee migration. Refugee advocates also contend the public has accepted increased surveillance and rights violations through the IRPA. The legislation "lessens the blow," so to speak, of the government limiting the freedoms of vulnerable refugees for the preservation of national security.

Securitization theory is a useful tool for human rights advocates in explaining the above contentions as well as the construction of a threat and how the threat of refugees has been portrayed to the Canadian public by the government. Securitization theory as developed by the Copenhagen School helps achieve this. Securitization is defined as:

"a speech act through which an inter-subjective understanding is constructed within a political community to treat something as an existential threat to a valued referent object and to enable a call for urgent and exceptional measures to deal with that threat. ${ }^{92}$

As stated above, securitization theory is inter-subjective. This means that the status of the securitizing agent, how the agents convey the threat, and how the audience perceive the threat come together to securitize a given object. The first component of securitization is the securitizing agent, which can be defined as the powerful group (or groups) that create the speech act to determine who poses a threat. Something can only become a security threat when it is labelled and transformed into a threat by the securitizing agent. ${ }^{93}$ Powerful groups creating the threats exist nationally and internationally. Terrorism and national security issues appeared at the

\footnotetext{
${ }^{91}$ Kruger, Mulder, and Korenic, "Canada after 11 September: Security Measures and "Preferred" Immigrants," 78.

${ }^{92}$ Barry Buzen, and Waever Ole , Regions and Powers: The Structure of International Security, (Cambridge: Cambridge University Press, 2003), 491.

${ }_{93}^{93}$ Rita Taureck, "Securitization Theory and Securitization Studies," Journal of International Relations and Development, no. 9 (2006): 54.
} 
forefront of political agendas after the 9/11 terror attacks. As a response to the attacks, the United Nations passed Security Council Resolution 1373 which obligated all states to stop the financing of all terrorist acts, criminalize the provision or collection of funds for terrorists, freeze funds and assets of individual involved in terrorism, as well as the exchange of information between nations regarding terrorist networks including false travel documents and communications technologies used by terrorist groups. ${ }^{94}$ As a result, terrorism legislation was enacted internationally, directly affecting relationships between the people and the state. The threat was clear: the world was fighting terrorists.

Moreover, following the attacks the international community began to link terrorist activity to refugees and asylum seekers, offering an example of the use of a speech act to securitize an object. Specifically, the UN Security Council Resolution 1373-the international response drafted following the attacks - mentions the "need to safeguard the system of international refugee protection from abuse by terrorists" twice throughout the resolution. ${ }^{95}$ Immediately, this gives the perception that terrorists are using refugee systems as a means to infiltrate nations and commit acts of terror. As a result, in some cases, refugees have become intrinsically (and wrongfully) linked to terrorism, and thereby identified as the threat.

In explicating a threat, the state has directed the expanse of this threat to an audience or 'referent object.' A referent object can be described as who or what is threatened in its existence by the threat. ${ }^{96}$ This is the second component within securitization theory. In trying to protect the nation from terrorist attacks, the referent object includes both the state and civilians as national

\footnotetext{
${ }^{94}$ United Nations Security Council, "Security Council Unanimously Adopts Wide-Ranging Anti-Terrorism Resolution: Calls for Suppressing, Financing, Improving International Cooperation,” last modified 2001, accessed July 18, 2013, http://www.un.org/News/Press/docs/2001/sc7158.doc.htm

${ }_{95}$ Ibid., 32.

${ }^{96}$ Taureck, "Securitization Theory and Securitization Studies," 54.
} 
security is a collective interest including everyone in the nation. ${ }^{97}$ Methods to protect the referent object from the identified threat violate rules that would otherwise have been obeyed, where the state claims a special right to use whatever means necessary to protect the referent object. ${ }^{98}$

Securitization theory explains how human rights advocates believe refugee policy went from refugee acceptant in the 1970s, 1980s, and 1990s to refugee excluding. However, human rights advocates believe this acceptant mentality was weakened with the implementation of the $I R P A$, as the government took a national security stance as oppose to increasing refugee protection measures. According to securitization theory, to prevent everything from being labelled a threat, a threat must be constructed as existential where "if [the problem] is not tackled, everything else will be irrelevant (because we will not be here or will not be free to deal with it in our own way). ${ }^{, 99}$ Subsequently, human rights advocates contend $9 / 11$ is used by the government as the foundation to allow for a re-conceptualization of refugee determination at a national level. The link between refugee and terrorism becomes more apparent as it is believed Canada responded to the terrorist threat with harsher and more restrictive immigration and refugee laws. As per securitization theory, this traumatic event has obviously been principal evidence used to empower governments to bring in restrictive immigration measures which otherwise could be rejected in a pre-9/11 context. Resultantly, human right advocates argue that a sense of urgency in drafting and implementing refugee policy occurs when the system was framed within the context of terrorism. As a climate of fear has developed around 9/11, refugee advocates believe the Canadian public accepts the IRPA as one solution towards combating

\footnotetext{
${ }^{97}$ Stoffman, Who Gets In: What's wrong with Canada's Immigration Program and how to fix it, 11.

${ }^{98}$ Holger Stritzel, "Towards a Theory of Securitization: Copenhagen and Beyond," European Journal of International Relations, 13, no. 3 (2007): 360.

${ }^{99}$ Taureck, "Securitization Theory and Securitization Studies," 54.
} 
terrorism and protecting the nation. ${ }^{100}$ Human rights supporters see the events of $9 / 11$ being used by the Canadian government as a justification for a "strong executive, unencumbered by norms of legality, to conduct the "war on terrorism"" through altering refugee policy. ${ }^{101}$ This gives the idea that Canada needs intense measures against refugees to benefit national security.

In applying this theory to the IRPA, authors fail to take into consideration that the IRPA was already in stages of being constructed long before $9 / 11$; it was not a spontaneous reaction to 9/11, as contended by securitization theory and rights activists. 9/11 simply expedited the passing of this act but was not the primary reason for the initial creation of the IRPA. The Immigration Act was in desperate need of amendment, which is arguably the main reason for overhauling the system and creating the IRPA. Additionally, refugee advocates do not consider public opinion in the passing of the IRPA after 9/11. Specifically, would the public have been outraged if the government did not react or create any form of new legislation in light of 9/11? It is safe to say Canadians would be infuriated if an attack was to happen against Canada and nothing was adopted to prevent it, especially after $9 / 11$. Furthermore, the theory can be critiqued on the basis that the relationship between the securitizing actor and the audience is very vague. The government is able to implement a specific policy but the audience is autonomous in deciding whether or not the policy is accepted. ${ }^{102}$ It is understood that the securitizing actor and the referent object have an intersubjective relationship, but the audience makes the decision as to whether or not to believe the state. Citizens use rationality and logic to determine which policies are just or unjust. Instead, this theory makes Canadian citizens sound like submissive robots that

\footnotetext{
${ }^{100}$ Russo, "Security, Securitization and Human Capital: The New Wave of Canadian Immigration Laws," 295. See also, Maria Lorena Cook, “The Advocate's Dilemma: Framing Migrant Rights in National Settings," Studies in Social Justice. no. 2 (2010): 155.

${ }^{101}$ Ibid., 295.

102 Stritzel, "Towards a Theory of Securitization," 363.
} 
inherently believe everything the government says, and agrees with or accepts every policy the government puts forth.

Moreover, rights advocates must remain mindful that the terrorist attacks (to date) were the worst assaults against the Western world. As discussed, terrorism is not a new threat to Canada; 9/11 simply drove the spectacle of terrorism into the homes of North Americans. One logical mode of facilitating security has been through migration simply because we do not know migrants' true intentions for entering the country, nor do we have a vast amount of background information about them. James Bissett supports this strategy in stating that "almost all of the known or alleged terrorists who have been apprehended in Canada have entered as asylum seekers."103 Additionally, Collacott argues that the refugee system is most commonly used by terrorists, to gain easy access into Canada. ${ }^{104}$ Gallagher supports this claim in stating that, "it is easier for an irregular migrant to secure permanent resident status [through the refugee determination system] in Canada than in any other developed country,"105 making it easier with permanent resident status to stay in Canada and facilitate terrorist activity. Although this paper focuses on refugee migration, the Nixon Center's study on 212 terrorists arrested or killed in North America between 1993 and 2003 concluded that "most immigrants are not terrorists, [but] most terrorists are immigrants." ${ }^{\prime 106}$ Moreover, Rohan Gunaratna - an international terrorism expert from the Nixon Center-stated that "all the major terrorist attacks that have been conducted in North American and Western Europe, with the exception of Oklahoma City, have been by terrorist groups that have recruited from the migrant communities or that have used the

\footnotetext{
${ }^{103}$ James Bissett, "Security Threats in Immigration and Refugee Policy," in Immigration Policy and the Terrorist Threat in Canada and the United States, edited by Alexander Moens, and Martin Collacott, 86, Vancouver 2008.

${ }^{104}$ Collacott, “Canada's Inadequate Response to Terrorism: the Need for Policy Reform,” 27.

${ }^{105}$ Stephen Gallagher, "Canada's Broken Refugee Policy System," 53.

${ }^{106}$ Robert Leiken, Bearers of Global Jihad? Immigration and National Security after 9/11, (Washington: Nixon Center, 2004) accessed July 23, 2013, http://www.mafhoum.com/press7/193S23.pdf, 14.
} 
migrant communities as a cover." ${ }^{107}$ In a 2002 interview, Harper admitted that even though he was pro-immigration, the "refugee determination process threatens national security by creating a backdoor immigration stream." ${ }^{108}$ Resultantly, the IRPA was an attempt to change the fundamental flaws of the Immigration Act, including mitigating the chances of terrorist entry and abuse of the system. As a discussed, the system has maintained the rights of refugees. Yet, there still exists several complications within the system: the need to increase national security through refugee determination, in order to protect its citizens, but do so in a manner which assists legitimate refugees and meets international refugee obligations.

These contentions (which will be discussed further) are supported by individuals who have actually worked first hand in immigration and refugee sectors, either internationally or with the Canadian federal government. Individuals who worked in policy and for the federal government include Arne Kislenko, James Bissett, Stephen Gallagher, and Martin Collacott. These scholars are able to provide first-hand experience in managing claims as they have put policy into practice. Scholars can actually speak as to whether or not the policies written on paper are practical in reality, thereby eliminating some bias in their findings. Moreover, most scholars have seen the development of refugee policy from the 1980s until present day and are able to accurately comment on the evolution and effectiveness of refugee policy. Bissett, Gallagher, and Collacott also write for the Fraser Institute. Bell writes as a very experienced journalist, particularly writing on terrorism for over twelve years. Also, he has travelled to countries engulfed in war and terrorism many within the Middle East, Pakistan, and Afghanistan, conducting interviews with terrorists and investigating international terrorist groups.

\footnotetext{
${ }^{107}$ Ibid.

${ }^{108}$ Russo, "Security, Securitization and Human Capital," 300.
} 
Amongst said authors, consensus exists that entry controls within the IPRA are problematic. In regards to entering a country, there are several stipulations that must be considered. First, the most relevant human right entitlement concerning refugees is the right to seek and enjoy asylum, as per Article 14 of the Universal Declaration of Human Rights. Basically, humans have the right to leave a country in which they "suffer profound violations human rights." 109 This implies that individuals are permitted to leave their own countries, if they are being persecuted for any of the reasons stated in the UN Convention. However, the granting of asylum is not automatic and states must use their discretion as to whether or not they will allow the individual into the country and subsequently accept the claim of an asylum seeker. ${ }^{110}$ This upholds states' sovereignty and enforces a standard which asylum seekers must meet to be granted refugee status. Thus, it is the sovereign right of the state to grant asylum, not the right of the individual to be granted asylum. ${ }^{111}$ Russo as well as Crépeau and Nakache take issue with sovereignty as they believe it excludes the individual and allows the state to rationalize rights violations. This claim raises several issues for rights advocates, arguing that sovereignty places the interest of the state and its society over asylum seekers through the use of refugee policy. People should not be excluded simply by virtue of state sovereignty. However, as a governing body of the people, the government must first and foremost use sovereignty to afford protection to the people it governs. There must be protection for the greater good of individuals before protection of the individual. Essentially, if there is a possibility that the greater good can be harmed, then the government has an obligation to act in the best interest of the Canadian people.

\footnotetext{
${ }^{109}$ Crépeau and Nakache, "Controlling Irregular Migration in Canada: Reconciling Security Concerns with Human Rights Protection," 6. See also, United Nations, "The Universal Declaration of Human Rights," last modified 2013, accessed June 26, 2013, http://www.un.org/en/documents/udhr/index.shtml

${ }^{110}$ Ibid.

${ }^{111}$ Christopher Wydrzynski, "Refugees and the Immigration Act,” McGill Law Journal, 25 (1979): 156.
} 
However, this doesn't imply that the individual or the refugee is not important. Anyone is still able to make an asylum claim in Canada. Canada cannot prevent the entry of anyone who claims asylum and is obliged to give anyone who is physically in the country protection under the Charter as per Singh. By virtue of this ruling, it is very difficult to keep terrorists and other security threats off Canadian soil. It is understood that there is no way to completely eliminate threats to national security. However, refugee policy must aim to reduce access to the system for inadequate claims, thereby making the system less vulnerable to exploitation. ${ }^{112}$

Unfortunately, Canada's refugee determination system does not fully utilize the available range of migration management mechanisms to curtail abuse of the determination system; ${ }^{113}$ vulnerability remains high. Entry controls within Canada's refugee system are deemed lenient not only by critics of the system but various countries around the world. The lack of an adequate detention policy is the first problematic aspect of entry control. Upon arriving to Canada, asylum seekers go through security screening to check their background and determine if anything exists that will deem them inadmissible on security grounds. However, these initial screenings are problematic. Firstly, it is quite a difficult task for immigration officials to screen for terrorists or accurately assess the background of an asylum seeker whose country of origin is halfway around the world, especially if the country of origin was plagued with war or if the country of origin did not maintain accurate records of its citizens. ${ }^{114}$ Furthermore, asylums seekers come to Canada without proper (or in many cases false) identification documents. It is understood that given their potentially horrible situation in their country of origin, it is impossible to have attained these necessary documents, as refugee advocates would argue.

\footnotetext{
${ }^{112}$ Kislenko, "Guarding the Border: Intelligence and Law Enforcement in Canada's Immigration System," 325.

${ }^{113}$ Stephen Gallagher, "Canada's Broken Refugee System: Reform is needed to screen out unfounded claims, "Fraser Forum (2008): 25, http://www.fraserinstitute.org/uploadedFiles/fraser-ca/Content/researchnews/research/articles/canadas-broken-refugee-system.pdf, accessed July 3, 2013.

${ }^{114}$ Bell, Cold Terror: How Canada Nurtures and Exports Terrorism Around the World, xiv.
} 
However, Canadian officials still have no definite indication as to who these people are and whether or not they are a risk to national security. A common scheme used by several asylum seekers includes the use of false identity documents, which is especially common when being smuggled by air into the country by international smugglers. Documents are given back to smugglers to be used again, appearing as if asylum seekers escaped their country without any form of documentation.

Lack of documents makes it increasingly difficult for Canadian officials to send an asylum seeker back to their country of origin. Kislenko, a former senior officer with Canadian Immigration, cites that "between 1990 and 2000 there were over 320000 refugee claims at airports port entry alone. Nearly 58000 people possessed fraudulent documents or no documents at all. $" 115$ What is more troubling is that the majority of illegal migrants are released into Canadian society without having undergone proper screening or any screening at all. ${ }^{116}$ In supporting the ineffective screening being conducted, James Bissett-a former Canadian ambassador - states: “After being fingerprinted and photographed [asylum seekers] are released and asked to show up at a refugee hearing which might be scheduled months in the future. Few are detained...none are screened for health, criminality or security...they are free to travel anywhere in Canada." ${ }^{\prime 17}$ The fear lies in the fact that there is no guarantee that asylum seekers will appear for trial, and many have the option of going underground, especially considering the vast size of Canada. Again, there is no concrete way to determine if one is or will become a

\footnotetext{
${ }^{115}$ Kislenko, "Guarding the Border: Intelligence and Law Enforcement in Canada's Immigration System," 323. See also, Bissett, "Security Threats in Immigration and Refugee Policy," 85.

${ }^{116}$ Ibid.

${ }^{117}$ Bissett, "Security Threats in Immigration and Refugee Policy," 88. See also, Alexander Moens, and Martin Collacott, "Immigration, National Security, and Canadian American Relations," Fraser Forum, January 2008, http://www.fraserinstitute.org/uploadedFiles/fraser ca/Content/research-news/research/articles/immigration-nationalsecurity-canada-us-relations.pdf, accessed July 13, 2013.
} 
terrorist simply through a security screening. However, in conducting a proper security screening, officials will significantly reduce risk and threats towards the Canadians.

One solution is to automatically detain asylum seekers until the refugee determination process is complete, thereby ensuring a certain degree of safety for Canadians. This occurs in various asylum seeking destinations, including the United States. Illegal migrants to Australia, for example, are automatically detained until health, identity, security checks or removal is completed. ${ }^{118}$ However, Canada is unable to automatically detain asylum seekers for an extended period because the refugee determination process takes too long to complete. ${ }^{119}$ As a result, detaining someone for the duration of the process would be unjust and inhumane.

It is understood that detention of an individual for an extended period of time (without reason) is controversial to one's rights yet, the main objective of the system should be to detain asylum seekers who's claims are least likely to be genuine, as to ensure a timely removal. ${ }^{120}$ Regrettably, Canadian law does not offer any safeguards within policy to allow for the quick deportation of those who are not legitimate refugees. Other countries distinguish and [detain] individuals "least likely to sustain an asylum application" 121 through using a manifestly unfounded policy, a safeguard that Canada has failed to employ. A manifestly unfounded policy involves asking a claimant upon arrival whether he or she has any claim that can potentially be recognized as a legitimate refugee claim. Again, various asylum seeking destinations employ this method of screening. For example, in the United Kingdom, a "clearly unfounded claim" exists

\footnotetext{
${ }^{118}$ Australian Human Rights Commission, “Asylum Seekers and Refugees," accessed July 17, 2013 http://www.humanrights.gov.au/publications/asylum-seekers-and-refugees.

${ }^{119}$ Gallagher, "Canada's Broken Refugee Policy System," 57. See also, Stephen Gallagher, "Canada's Dysfunctional Refugee Determination System: Canadian Asylum Policy from a Comparative Perspective," Public Policy Sources. no. 78 (2003): 27, http://www.immigrationwatchcanada.org/wpcontent/uploads/2010/11/refugee_pps781.pdf (accessed July 3, 2013).

${ }^{120}$ Stephen Gallagher, "Canada's Dysfunctional Refugee Determination System: Canadian Asylum Policy from a Comparative Perspective," 27

${ }^{121}$ Ibid.
} 
whereby the individual has no grounds for claiming asylum. Asylum seekers are able to appeal the decision but must do so from outside the UK. ${ }^{122}$ In order to be allowed a full assessment of their claims, asylum seekers to the USA, must have a "credible fear" of persecution where, if they cannot convince the immigration officer of this credible fear, they will be deported. ${ }^{123}$ The lack of manifestly unfounded policy allows asylum seekers in Canada to receive a full assessment of their claims. Regardless of whether or not the claim is credible, asylum seekers landing in Canada receive a full assessment simply by virtue of making a claim. For example, one man from Poland attempted to claim refugee status stating that he would relapse into alcoholism if sent back to Poland. In Canada, he cannot be denied access to a full refugee determination hearing, inclusive of a federal court review. ${ }^{124}$ As a result of a lack of manifestly unfounded policy and a full review of one's claim, detention becomes impossible as the assessment could take years to complete.

A second safeguard lacking within the refugee determination system is a designated country of origin (DCO) policy. If the asylum seeker originates directly from a safe country whose government is democratic, respective of the rule of law, is unsupportive of the actions being done onto the claimant and has the ability to take legal action and prevent the abuse, Canada should not be accepting refugees from these countries. Instead, claimants' country of origin and their government should be the first instance of complaint; asylum should not be the first solution taken by claimants to seek means to their troubles. To support this, countries of the EU "will not accept refugee claims from people who come from countries that are signatories to

\footnotetext{
${ }^{122}$ UK Border Agency, "When Do I Have a Right to Appeal," last modified 2012, accessed July 17, 2013, http://www.ukba.homeoffice.gov.uk/asylum/outcomes/unsuccessfulapplications/appeals/righttoappeal/

${ }_{123}^{123}$ Gallagher, "Canada's Broken Refugee Policy System," 57.

${ }^{124}$ Ibid., 58.
} 
the UN Refugee Convention, are democratic, and follow the rule of law." ${ }^{\prime 25}$ Refugee advocates deem this policy to be very controversial. Human rights allege that each asylum claim needs to be looked at as its own entity and cannot be determined based on the political structure of a country. A claim for refuge is subjective and needs to be determined based on the individual characteristics of that claim. ${ }^{126}$ However, Canada disregards the implications of accepting asylum seekers from safe third countries. Canada is essentially damaging its relations with safe countries. In accepting refugees from these countries, Canada is indirectly deeming these countries as undemocratic and abusive to the people, where the governments of said countries are standing by as abuse takes place, thereby not acting as responsible governments and embarrassing them on an international scale.

Because a manifestly unfounded policy and DOC does not exist within the IRPA, the slow removal process of asylum seekers (who do not have a legitimate claim and come from safe countries) delays the process for legitimate claims to be heard, thus numerous refugee claimants are dragged through the system creating a backlog. As of 2009, IRB determinations took approximately 18 months because of the backlog. ${ }^{127}$ The wait time for legitimate refugees is approximately 20 months because of the enormous backlogs the system experiences with unfounded claims. ${ }^{128}$ Additionally, asylum seekers receive expanded time in Canada allowing them to settle, work, and raise a family. Having the above safeguards would allow officials to expedite claims, thereby reducing the backlog caused by unfounded cases. Moreover, manifestly

\footnotetext{
${ }^{125}$ Bissett, "Security Threats in Immigration and Refugee Policy," 88.

${ }^{126}$ Margaret Wente, "When it comes to refugee claims, it's pretty easy to ID the 'safe' countries," Globe and Mail, sec. Commentary, March 31, 2010, http://www.theglobeandmail.com/commentary/when-it-comes-to-refugeeclaims-its-pretty-easy-to-id-the-safe-countries/article4321353/ (accessed July 17. 2013).

${ }^{127}$ Peter Showler, "Fast, Fair and Final: Reforming Canada's Refugee System." (unpublished working paper., Maytree Foundation, 2009: 4), accessed July 13, 2013, http://www.cdp-hrc.uottawa.ca/projects/refugeeforum/publications/FastFairAndFinal.pdf

${ }^{128}$ Government of Canada, "ARCHIVED - Regulations Amending the Immigration and Refugee Protection Regulations," Canada Gazette, 145, no. 12 (2011): 973, http://www.gazette.gc.ca/rp-pr/p1/2011/2011-03-19/pdf/g114512.pdf
} 
unfounded policy and DCO would deter asylum seekers who are not in genuine need of protection from coming to Canada, as quick determination would reduce access to the overall refugee system and increase removal times. ${ }^{129}$ It would also ensure a timely removal of possible security threats, thereby reducing the vulnerability of the system and increasing the safety of Canadians.

It should be noted that manifestly unfounded calms and DCO did not exist within the IRPA until recently with the passing of the Balanced Refugee Reform Act and Protecting Canada's Immigration System Act, which amend the IRPA. The RPD at the IRB determines if a claim is manifestly unfounded, rejecting the claimant from accessing the RAD. ${ }^{130}$ Nevertheless, failed claimants will still have access to the Federal Court to stage an appeal. This legislation has only been in effect for approximately seven months since the writing of this paper. Thus, it is too early to determine whether or not manifestly unfounded policy and DCO are sufficient to amend some of the problems within the refugee determination system. Moreover, policies must eventually be tested by the Courts against the Charter, to determine if the laws are actually credible and whether or not the rights of the individual are being breached.

In addition to not implementing manifestly unfounded claims or DCO policies, the countless avenues of appeals available to asylum seekers within the determination system are also problematic. Having numerous appeal routes not only demonstrates an additional reason as to why automatic detainment policy would be inappropriate (because of the extensive time frame) but in itself is a criticism of the refugee determination process. Within Canadian law, everyone has the right to appeal. However, a single appeal should be sufficient enough to meet not only Canadian law standards but also international law standards. Multiple appeal process for

\footnotetext{
${ }^{129}$ Ibid.

${ }^{130}$ Citizenship and Immigration Canada, "Identifying Unfounded Claims," last modified December 02, 2012, http://www.cic.gc.ca/english/refugees/reform-claims.asp
} 
claimants simply delays their deportation. Until recently, the IRB would determine claimants' eligibility, whereas a formal appeal (based on law or fact) would be executed with the Federal Court of Appeal. As of December 2012, the Canadian government has created the Refugee Appeal Division (RAD) as a separate branch of the IRB to hear denied claimants. Again, the success of the RAD has yet to be seen as it implementation is so recent.

Before the establishment of the RAD, an 'appeal' should be interpreted as a 'methods to avoid deportation.' Asylum seekers encounter three additional stages from their initial claim. First, the IRB determines if the claim is eligible. If not, a failed claimant is able to apply for a PRRA as well as a stay through $\mathrm{H} \& \mathrm{C}$. The success rate of failed claimants through seeking a PRRA or stay through of $\mathrm{H} \& \mathrm{C}$ is irrelevant. The issue at hand is the amount of time it takes for a failed claimant to go through said processes which increases the amount of time they can stay in the country. For example, it takes between one to three years before the PRRA process simply begins. ${ }^{131}$ If the PRRA is denied, a judicial review of the PRRA decision is an additional option failed claimants have to increase their time in Canada. Additionally, if a claim is denied under PRRA, it takes about sixteen months from notice of removal to physical removal of the failed claimant. ${ }^{132}$

With refugee determination, time is of the essence. The longer an individual resides in Canada, the more established they become in terms of a job and a family thereby reducing the chances of deportation. Because these smaller safeguards (e.g. manifestly unfounded policy, DCO) are unavailable, failed claimants are able to seek other means to stay in Canada through appeal to the Federal Court and subsequently PRRA and H\&C. According to Citizenship and Immigration Canada, processing a claim "takes [about] four and a half years from the initial

\footnotetext{
${ }^{131}$ Showler, "Fast, Fair and Final: Reforming Canada's Refugee System," 5.

${ }^{132}$ Ibid.,8.
} 
claim until the removal of a failed asylum claimant and in some cases 10 years or longer.",133 This seemingly unrestricted timeline of processing an application is ridiculous and has negative consequences. Firstly, delays are occurring for those who have legitimate claims. Secondly, the length of time one can potentially spend in Canada through claiming refuge ultimately attracts individuals with unfounded claims as they have reason to believe that they can also fool the system. Moreover, the system serves as a way for failed claimants to delay deportation and increase the length of time one can stay in Canada. In many cases, some individuals are able to avoid deportation all together. Most importantly, the extensive amount of time asylum seekers are eligible to stay in Canada leaves the nation vulnerable to security threats.

This argument is not insinuating that individuals should receive a simple, brief review of their claim. A claimant should always be given a fair assessment of his or her claim, as this is not only moral and just, but also meets Canada's obligations under the UN Convention. Accuracy, fairness, and efficiency are essential within refugee determination as claimants face persecution, loss of life, torture if negative decisions are made. ${ }^{134}$ However, the integrity of the system is currently being undermined. Clearly, the positive development of policy towards a more efficient and secure system since the Immigration Act remains in question. Canada's refugee determination system is inefficient and the entire process allows an individual to maximize the length of time spent in Canada, also giving an individual the option of going underground, thereby avoiding deportation. Lack of quick determination safeguards including, manifestly unfound policy, or DCO in combination with numerous appeal avenues, creates an excruciatingly long process. Increased concern for national security results from insufficient controls and lengthy process, as potential terrorists have several routes to maximize their time in

\footnotetext{
${ }^{133}$ Government of Canada, "ARCHIVED — Regulations Amending the Immigration and Refugee Protection Regulations," 973.

${ }^{134}$ Showler, "Fast, Fair and Final," 9-10.
} 
Canada and assist international terrorist organizations. Specifically, lack of manifestly unfounded and detainment policy allows claimants to travel freely throughout Canada, without any means for tracking them, before officials are able to determine whether or not they pose a threat to national security. It will be very difficult to maintain the human rights that Canadians value without security, "if a country cannot defend itself effectively, it will not be in a position to promote or preserve human rights." ${ }^{135}$ The Canadian refugee system is so generous and lengthy where, even if a claim is rejected, "irregular migrants face a toothless and maze-like appeal and removal system." 136 Furthermore, Canada "compounds this folly by forfeiting its right to remove dangerous criminals and terrorists;" it has effectively abandoned its sovereignty. ${ }^{137}$

The attempted Via Rail bombings in Toronto could not have come at a more appropriate time to the writing of this paper. On April 22, 2013, Chihed Esseghaier and Raed Jaser were arrested and are accused of "plotting to derail a Via passenger train," in an al-Qaeda supported terrorist attack. ${ }^{138}$ Neither Jaser nor Esseghaier are Canadian citizens. In fact, Jaser was a failed refugee claimant that Canadian authorities tried to deport nine years ago, but were clearly unsuccessful. The story of Jaser perfectly depicts the multiple flaws in Canada's refugee determination system, which this paper has attempted to reveal. Firstly, Jaser and his family came from Germany (a safe, democratic country) with fake documents. At the time of the claim, Jaser was a dependent minor. Nevertheless, the family was denied refugee status, but appealed. By the time his family's appeal was granted, Jaser had criminal convictions including fraud and

\footnotetext{
${ }^{135}$ Collacott, "Canada's Inadequate Response to Terrorism: the Need for Policy Reform," 65.

${ }^{136}$ Gallagher, "Canada's Broken Refugee Policy System,” 26.

${ }^{137}$ Bissett, "Security Threats in Immigration," 88.

${ }^{138}$ CBC News, "Canada Tried to Deport Terror Suspect Raed Jaser," last modified April 26, 2013, accessed July 8, 2013, http://www.cbc.ca/news/canada/story/2013/04/25/via-train-terror-plot.html. See also, Anna Mehler Paperny, Global News, "Train Terror Suspect Raed Jaser Dodged Deportation for Years," last modified April 25, 2013, accessed July 18, 2013, http://globalnews.ca/news/511849/prior-fraud-conviction-almost-led-to-deportation-of-onevia-rail-terror-suspect/
} 
utterance of death threats. In 2004 a warrant was issued for his arrest and deportation. ${ }^{139}$ According to the $\mathrm{CBC}$ report, Jaser was granted pardon on said charges and shortly after, permanent resident status. What is baffling about this story is that an individual, who was illegally living in Canada, not only was convicted of criminal offences, but was pardoned for said offences even though he had no right to be in Canada in the first place. As stated perfectly by former Minister of Citizenship and Immigration Jason Kenney, “it seems to me that if you're inadmissible as a foreign national that should preclude you from applying for a pardon."140 Although he wrongly misuses the term foreign national, it is understood that one should not be granted pardon if they are living in Canada illegally with criminal charges.

As exemplified, the Canadian refugee system can be easily exploited by terrorists as a point of entry, to harm Canada as well as the entire international community. This is simply one example of a failed refugee application and deportation that snowballed into a potential catastrophe. In 2008, 42000 were ordered deported from Canada (after all their appeal options were exhausted), of which $15 \%$ were convicted of criminal acts. ${ }^{141}$ Without any existing safeguards upon entry into Canada, the chances of terrorist slipping through the refugee system are increased. Not only has Canada given a home to terrorists, but Canada "has [also] provided haven, money, propaganda, weapons and foot soldiers to the globe's deadliest religious, ethnic and political extremists' movements, murderous organizations that have brought their wars with them, turning the country into a base for international terror." ${ }^{\text {"142 }}$ Criticism towards the act is by

\footnotetext{
${ }^{139}$ CBC News, “Canada Tried to Deport," accessed July 8, http://www.cbc.ca/news/canada/story/2013/04/25/viatrain-terror-plot.html

${ }^{140}$ Stewart Bell, "Ottawa to Close 'loophole' After Learning VIA Terror Suspect had Crimes Pardoned,"National Post, sec. Politics, June 02, 2013, accessed July 18, 2013, http://news.nationalpost.com/2013/06/02/ottawa-to-closeloophole-after-learning-via-terror-suspect-had-crimes-pardoned/

${ }^{141}$ Scott Newark, interview by Macdonald-Laurier Institute, "Scott Newark on Immigration and National Security," Straight Talk, January 2013:4, accessed July 22, 2013, http://www.macdonaldlaurier.ca/files/pdf/StraightTalk-Newark-Immigration-and-National-Security4.pdf

${ }^{142}$ Bell, Cold Terror: How Canada Nurtures and Exports Terrorism Around the World, xiii.
} 
no means an attempt to dispute Canada's humanitarian effort towards refugees. But, one must question the status of these individuals and whether or not Canada is assisting legitimate refugees or helping terrorists settle within the borders of a safer, wealthier more convenient location to access the rest of the world. Resultantly, compared to any other country in the world (aside from the United States), Canada has the most diverse and highest number of known terrorist groups. ${ }^{143}$ Canada's immigration policies have not only failed in its responsibility to provide security to Canadians, but have also the failed the legitimate, deserving refugees of the world.

In terms of Canada's obligation to legitimate refugees, there is consent with refugee advocates that legitimate refugees are not being let into the country. Canada's international obligation to refugees is not being fulfilled. However, the evidence this paper uses to support this contention is extremely different. Refugee advocates deem the refugee policy as too stringent, as Canada is limiting the amount of refugees (and potentially legitimate refugees) it allows within its borders because of the definition of terrorism and powers of immigration officials. Conversely, Canada's refugee determination system is in fact doubly flawed. Firstly, as discussed, the system has several loopholes to allow potential exploitation and entry of terrorists. Additionally, the system lacks important safeguards to detect illegitimate claims and terrorist threats to Canada, but also to deport illegal immigrants as soon as possible. Secondly, the system favours individuals who actually have the resources to get to Canada. Canadian borders are open to individuals who are able to access it (e.g. have the means or money to travel to Canada), thereby actively discriminating against those who do not have any means to reach our borders. Current policy is reactive as it targets people who are refugee claimants, as opposed to being proactive and assisting legitimate refugees. This is not to say that asylum seekers showing up at

\footnotetext{
${ }^{143}$ Martin Collacott, "Canada Must Remain Vigilant Against Terrorism," Fraser Forum (2006): 7, accessed June 11, 2013, http://www.fraserinstitute.org/uploadedFiles/fraser-ca/Content/researchnews/research/articles/VigilantAgainstTerrorism.pdf.
} 
Canadian borders do not have legitimate claims. Courage and perseverance are required to leave one's country and reach Canada, especially from the other side of the globe. This, however, does not negate the fact that Canada still has a predominantly reactive and discriminatory system; the system is largely open to those with the funds to reach Canada. Canada is not distinguishing between legitimate convention refugees and refugee claimants. ${ }^{144}$ As a result, minimal protection is afforded to the refugees who need it most.

As Canada is focused on the backlog and ineffectiveness of its own system, a more pressing issue is being ignored: refugee camps in third world countries. Two thirds of the world's refugees (over seven million people) are trapped in protracted refugee situations (PRS). ${ }^{145}$ A PRS "refer to situations in which refugees have lived in exile for five years or more, and there is a low likelihood of resolving their situation..." ${ }^{146}$ There are over 30 PRS throughout the world, where refugees are spending approximately twenty years in such situations. ${ }^{147}$ Furthermore, $90 \%$ of genuine refugees are women and children found in third world refugee camps cared for by the United Nations. ${ }^{148}$ Stoffman states that, "Canadians are generous and eager to help real refugees. But this generosity is abused because Canada now admits, at great cost to taxpayers, thousands of people who are not refugees by the standards of the rest of the world while offering meagre support to the 21 million genuine refugees stranded in third world camps."149

Canada has been unable to assist genuine refugees in these countries because of the influx and mismanagement of asylum seekers at our borders. Compared to other Western nations,

\footnotetext{
${ }^{144}$ Stoffman, Who Gets In: What's wrong with Canada's Immigration Program and how to fix it, 5.

${ }^{145}$ Gil Loescher, James Milner, Edward Newman, and Gary Troller, "Introduction." In Protracted Refugee Situations: Political Human Rights and Security Implications, 3-19, Hong Kong: United Nations University Press, 2008.

${ }^{146}$ Refugee Studies Center, "Protracted Refugee Situations," last modified January 29, 2012, accessed July 22, 2013, http://www.prsproject.org/

${ }^{147}$ Loescher et al., "Introduction," 3. See also, Refugee Studies Center, "Protracted Refugee Situations," last modified January 29, 2012, accessed July 22, 2013, http://www.prsproject.org/

${ }^{148}$ Stoffman, Who Gets In: What's wrong with Canada's Immigration Program and how to fix it, 159.

${ }^{149}$ Ibid., 158.
} 
funding from the Canadian government to assist the UNHCR operate refugee camps, has been minimal. Stoffman cites Bissett, also the former head of Canadian Immigration Service, who stated, "I've been in the camps and they are dreadful with little food and shelter [...] we give the camps only between $\$ 20$ million and $\$ 25$ million a year. If you're a refugee in Sierra Leone, you'll get no help from us. These are the genuine refugees that need Canada's compassion and tax dollars, not the (majority) of refugees appearing at our borders. This is an absolute disgrace. ${ }^{150}$ Spending on international refugee aid is minimal in contrast to what Canada spends on its refugee determination program. $\$ 2$ to 4 billion of Canadian's tax dollars are being spent on claimants. This comes out to about $\$ 50000$ spent on each claimant coming to Canada, where contributions to refugee camps amounts to a pitiful dollar a year per person. ${ }^{151}$ Furthermore, before coming to Canada, $15 \%$ of claimants already settled in a safe third country. ${ }^{152}$ Article 31of the Convention and Protocol Relating to the Status of Refugees states: "the Contracting States shall not impose penalties on account of their illegal entry of presence on refugees who, coming directly from a territory where their life or freedom was threatened in the sense of Article $1 .{ }^{, 153}$ Such individuals do not fit the definition of a Convention refugee as they are not coming directly from a country in which they are endangered. People who are already settled in a safe country before coming to Canada are not subject to persecution. Canada provides generous social support to refugees inclusive of work permits, health care and welfare. This attracts not only terrorists but those who are not in genuine need of protection. The minimal support offered to refugees in camps compared to the assistance handed to claimants in Canada truly questions Canada's humanitarian efforts.

\footnotetext{
${ }^{150}$ Ibid., 159.

${ }^{151}$ Collacott, “Canada's Inadequate Response to Terrorism: the Need for Policy Reform,” 47.

${ }^{152}$ Stoffman, Who Gets In: What's wrong with Canada's Immigration Program and how to fix it, 153.

${ }^{153}$ United Nations High Commissioner for Refugees. Convention and Protocol, 31.
} 
The Canadian government has much work to do in the near future to amend the refugee determination system. As argued, Canada's system is overtly discriminatory, as it simply reacts to refugee claims. Comparatively, Canada does little to assist legitimate refugees living in camps on the other side of the world. Thus, claims that Canada is upholding its humanitarian and international obligations towards one of the world's most vulnerable population are fallacious. Yet, in the areas examined, refugee policy has successfully upheld the rights of claimants coming into Canada, contrary to what many refugee activists proclaim specifically about the definition of terrorism and violations of one's equality rights. In this regard, Singh is a particularly significant case for refugees, giving rights to everyone in Canada. However, what is increasingly troubling is the disregard for the nation's security and subsequently the security of Canadian citizens. Seemingly, the government has given rights to non- citizens but at the same time has neglected the security of Canadians. The lack of detainment policy, manifestly unfounded policy, DCO and the countless avenues of appeals granted to asylum seekers leaves Canada vulnerable. Lack of safeguards not only allow dubious claims to enter the country, but paves a pathway for terrorists to gain access to our country and inflict harm on our people in addition to having a secure "terrorist home-base" to comfortably inflict terror on the rest of the world. The mobility of people around the world and entry of migrants into Canada will only increase with further advancements in technology. As stated, new policy changes have been implemented as of December 2012. It is only a matter of time until we see how effective such implementations are. In the meantime, Canada needs to work towards assisting refugees abroad and protecting the security of their citizens within. Hopefully, a drastic change from the era of the Immigration Act will be evident in the future. 


\section{LIST OF APPENDICES}

\section{Appendix 1: Statutory Provisions (Excerpts of Relevant Provisions)}

\section{Canadian Charter of Rights and Freedoms}

S. 1

The Canadian Charter of Rights and Freedoms guarantees the rights and freedoms set out in it subject only to such reasonable limits prescribed by law as can be demonstrably justified in a free and democratic society.

S. 7

Everyone has the right to life, liberty and security of the person and the right not to be deprived thereof except in accordance with the principles of fundamental justice.

S. 15

(1) Every individual is equal before and under the law and has the right to the equal protection and equal benefit of the law without discrimination and, in particular, without discrimination based on race, national or ethnic origin, colour, religion, sex, age or mental or physical disability.

S. 24

(1) Anyone whose rights or freedoms, as guaranteed by this Charter, have been infringed or denied may apply to a court of competent jurisdiction to obtain such remedy as the court considers appropriate and just in the circumstances.

...

S. 52

(1) The Constitution of Canada is the supreme law of Canada, and any law that is inconsistent with the provisions of the Constitution is, to the extent of the inconsistency, of no force or effect. 


\section{Appendix 2: Canadian Cases Cited}

Singh v. Canada (Minister of Employment and Immigration) [1985] S.C.R. 177.

R. v. Lifchus, [1997] 3 S.C.R. 320

\section{Appendix 3: Statutes Cited}

1951 UN Refugee Convention Relating to the Status of Refugees

Canadian Charter of Rights and Freedoms

Criminal Code, RSC 1985, c C-46 s 745.

Immigration Act, R.S.C. 1985

Immigration and Refugee Protection Act, S.C. 2001, c 27

Universal Declaration of Human Rights 


\section{BIBLIOGRAPHY}

Aiken, Sharryn J. "National Security and Canadian Immigration: Deconstructing the Discourse of Trade-Offs." In The Complex Dynamics of International Migration, edited by Francios Crépeau, 172-199. Montreal: Presses de l'Universite de Montreal, 2009.

Anti-Defamation League, "Canada and Terrorism." Last modified January 2004. Accessed July 8, 2013. http://archive.adl.org/terror/tu/tu_0401_canada.asp.

Australian Human Rights Commission, “Asylum Seekers and Refugees.” Accessed July 17, 2013. http://www.humanrights.gov.au/publications/asylum-seekers-and-refugees.

Bell, Stewart. Cold Terror: How Canada Nurtures and Exports Terrorism Around the World. Toronto: John Wiley \& Sons Canada Ltd., 2004.

---. 'Ottawa to Close 'loophole' After Learning VIA Terror Suspect had Crimes Pardoned." National Post, sec. Politics, June 02, 2013. http://news.nationalpost.com/2013/06/02/ottawa-to-close-loophole-after-learning-viaterror-suspect-had-crimes-pardoned/ (accessed July 18, 2013).

Bhabha, Faisal. "Tracking 'Terrorists' or Solidifying Tereotypes? Canada's Anti-Terrorism Act in Light of the Charter's Equality Guarantee." Windsor Review of Legal and Social Issues. no. 96 (2003): 95-136.

Bissett, James. "Security Threats in Immigration and Refugee Policy." In Immigration Policy and the Terrorist Threat in Canada and the United States, edited by Alexander Moens, and Martin Collacott, 75-94. Vancouver 2008.

Brooks, Risa. "Muslim 'Homegrown' Terrorism in the United States: How Serious Is the Threat?." International Security. no. 2 (2011): 7-47. http://belfercenter.hks.harvard.edu/files/Muslim Homegrown Terrorism in the United States.pdf (accessed June 24, 2013).

Buzen, Barry, and Waever Ole. Regions and Powers: The Structure of International Security. Cambridge: Cambridge University Press, 2003.

Carlson, Katheryn. "Record number of Hungarian asylum-seekers landing on Canada's doorstep." National Post, November 4, 2011. Accessed August 27, 2013. http://news.nationalpost.com/2011/11/04/record-number-of-hungarian-asylum-seekerslanding-on-canadas-doorstep/.

Canadian Border Services Agency, "Fact Sheet- Removals.” Last modified January 08, 2013. Accessed August 11, 2013. http://www.cbsa-asfc.gc.ca/media/facts-faits/051-eng.html.

“Canada: C-11, Professionals, Mexicans.” Migration News 8, no. 6 (2001): Accessed June 6, 2013. http://migration.ucdavis.edu/mn/more.php?id=2384_0_2_0. 
Canadian Council for Refugees. "Talking about Refugees and Immigrants: A Glossary of Terms.” Accessed June 24, 2013. http://ccrweb.ca/glossary.PDF.

CBC News, "Canada Tried to Deport Terror Suspect Raed Jaser." Last modified April 26, 2013. Accessed July 18, 2013. http://www.cbc.ca/news/canada/story/2013/04/25/via-trainterror-plot.html.

---. “Kenney names 27 countries as 'safe' in refugee claim dealings.” Last modified 14, 2013. Accessed August 27, 2013. http://www.cbc.ca/news/canada/story/2012/12/14/polimmigration-safe-third-countries-dco-kenney.html.

Citizenship and Immigration Canada, "Archived- Forging Our Legacy: Canadian Citizenship and Immigration, 1900-1977.” Last modified July 01, 2006. Accessed July 3, 2013. http://www.cic.gc.ca/english/resources/publications/legacy/chap-6.asp.

---, “ENF 20: Detention.” Last modified Sept. 26, 2007. Accessed July 5, 2013. http://www.cic.gc.ca/english/resources/manuals/enf/enf20eng.pdf.

---, "Humanitarian and Compassionate Grounds." Last modified October 26, 2012. Accessed July 18, 2013. http://www.cic.gc.ca/english/refugees/inside/h-and-c.asp.

---, "Identifying Unfounded Claims.” Last modified December 02, 2012. Accessed July 17, 2013. http://www.cic.gc.ca/english/refugees/reformclaims.asp.

---, "PP 1 Processing claims for refugee protection in Canada." Last modified February 17, 2012. Accessed July 4, 2013. www.cic.gc.ca/english/resources/manuals/pp/pp01-eng.pdf.

Crépeau, Francois, and Nakache, Delphine. "Controlling Irregular Migration in Canada: Reconciling Security Concerns with Human Rights Protection.” IRPP Choices, 12, no. 1 (2006): 3-30.

Collacott, Martin. Canada's Inadequate Response to Terrorism: the Need for Policy Reform. Fraser Institute Digital Publication, 2006. Accessed June 12, 2013. http://www.fraserinstitute.org/WorkArea/DownloadAsset.aspx?id=2334.

---, Martin. “Canada Must Remain Vigilant Against Terrorism.” Fraser Forum. (2006): 711. http://www.fraserinstitute.org/uploadedFiles/fraser-ca/Content/researchnews/research/articles/VigilantAgainstTerrorism.pdf (accessed June 11, 2013). 
---, Martin. Terrorism, Refugees and Homeland Security. National Library of Canada Cataloguing in Publication Data, 2002. http://www.immigrationwatchcanada.org/wpcontent/uploads/2010/11/rmc_collacott_15mar.pdf (accessed July 9, 2013).

Cook, Maria Lorena. "The Advocate's Dilemma: Framing Migrant Rights in National Settings." Studies in Social Justice. no. 2 (2010): 145-164.

Diab, Robert. Guantánamo North: Terrorism and the Administration of Justice in Canada. Halifax: Fernwood Publishing, 2008. Edwards, Alice. "Human Security and the Rights of Refugees: Transcending Territorial and Disciplinary Borders." Michigan Journal of International Law. no. 3 (2009): 763-807.

Economic Council of Canada. Economic and Social Impacts of Immigration: A Research Report. Ed. Neil Swan et al. Ottawa: The Council, 1991.

Edwards, Alice. "Human Security and the Rights of Refugees: Transcending Territorial and Disciplinary Borders." Michigan Journal of International Law. no. 3 (2009): 763-807.

Gallagher, Stephen. "Canada's Broken Refugee Policy System." In Immigration Policy and the Terrorist Threat in Canada and the United States, edited by Alexander Moens, and Martin Collacott, 53-74. Vancouver 2008.

---, Gallagher, "Canada's Broken Refugee System: Reform is needed to screen out unfounded claims, "Fraser Forum (2008): 25-27. http://www.fraserinstitute.org/uploadedFiles/fraser-ca/Content/researchnews/research/articles/canadas-broken-refugee-system.pdf (accessed July 3, 2013).

---, Stephen. "Canada's Dysfunctional Refugee Determination System: Canadian Asylum Policy from a Comparative Perspective." Public Policy Sources. no. 78 (2003): 1-40. http://www.immigrationwatchcanada.org/wpcontent/uploads/2010/11/refugee_pps781.pdf (accessed July 3, 2013).

Government of Canada. "ARCHIVED - Regulations Amending the Immigration and Refugee Protection Regulations." Canada Gazette. no. 12 (2011): 931-1066. http://www.gazette.gc.ca/rp-pr/p1/2011/2011-03-19/pdf/g1-14512.pdf (accessed July 18, 2013).

Griego, Manuel Garcia. "Canada: Flexibility and Control in Immigration and Refugee Policy." In Controlling Immigration: A Global Perspective, edited by, Cornelius, Wayne A., Philip L. Martin, and James Frank Hollifield, 118-140. Stanford, California: Stanford University Press, 1994.

Hanson Njoh Sone, The Detention and Deportation of Convention Refugees on Grounds of Criminality and National Security in Canada: Challenges and Justifications, (A Thesis Submitted to the Faculty of Graduate Studies: Graduate Program in Law. 2008) 
Haque, Shamsul. "Government Responses to Terrorism: Critical Views of their Impacts on People and Public Administration.” Public Administration Review. (2002): 170-180.

Hoffman, Paul. "Human Rights and Terrorism.” Human Rights Quarterly. (2004): 932-955.

Howard, Rhoda. "Contemporary Canadian Public Policy: A Critical Assessment." Canadian Public Policy. no. 2 (1980): 361-373.

Irvine, Sandy. "Canadian Refugee Policy: Understanding the Role of International Bureaucratic Networks in Domestic Paradigm Change." In Policy Paradigms, Transnationalism, and Domestic Politics, edited by Grace Darlene Skogstad. Toronto: University of Toronto Press, 2011.

Jackson, Pamela Irving, and Roderick Parke. "Globalization and the Secularization of Immigration Policy: Competing Influences on Immigrant Integration Policy in Germany, France, Britain, and the United States." Human Architecture. no. 4 (2006): 131-146.

Jenkins, David. "In Support of Canada's Anti-Terrorism Act: A Comparison of Canadian, British, and American Anti-Terrorism Law." Saskatchewan Law Review. (2003): 419454.

Jones, Martin, and Sasha Baglay. "Canadian Refugee Policy.” In Refugee Law, 1-29. Toronto: Irwin Law, 2007.

Kelley, Ninette, and M. J. Trebilcock. The Making of the Mosaic: A History of Canadian Immigration Policy. Toronto: University of Toronto Press, 1998.

King, Michael, Ali Mohamed, and Farah Aw-Osman. Terror in the Peaceable Kingdom: Understanding and Addressing Violent Extremism in Canada. Edited by Frum Linda, and Daveed Gartenstein-Ross. Washington, D.C.: FDD Press, 2012.

Kislenko, Arne. "Guarding the Border: Intelligence and Law Enforcement in Canada's Immigration System." In The Oxford Handbook of National Security Intelligence, edited by Loch Johnson, 310-327. New York: Oxford University Press, 2010.

Kruger, Erin, Marlene Mulder, and Bojan Korenic. "Canada after 11 September: Security Measures and "Preferred" Immigrants." Mediterranean Quarterly. no. 4 (2004): 72-87.

Lebel-Grenier, Sébastien. "The Charter and Legitimization and Judicial Activism". In Judicial Power and Canadian Democracy, P. Howe and P. Rusell, Eds., McGill- Queen's University Press: Montreal. 2001.

Leiken, Robert. Bearers of Global Jihad? Immigration and National Security after 9/11. Washington: Nixon Center, 2004. http://www.mafhoum.com/press7/193S23.pdf (accessed July 23, 2013). 
Lilley, Brian. "We can't even kick out the terrorists." Toronto Sun, sec. Opinion, March 11, 2011.http://www.torontosun.com/comment/columnists/brian_lilley/2011/03/10/1757505. html (accessed July 10, 2013).

Liu, Elizabeth. Centre for Constitutional Studies, "Security Certificates.” Last modified 2013. Accessed August 1, 2013. http://www.law.ualberta.ca/centres/ccs/issues/securitycertificates.php.

Loescher, Gil, James Milner, Edward Newman, and Gary Troller. "Introduction." In Protracted Refugee Situations: Political Human Rights and Security Implications, 3-19. Hong Kong: United Nations University Press, 2008.

Manfredi, Christopher P. Judicial Power and the Charter: Canada and the Paradox of Liberal Constitutionalism $2^{\text {nd }}$ ed. Toronto: Oxford University Press. 2001

Moens, Alexander, and Martin Collacott. "Immigration, National Security, and Canadian American Relations.” Fraser Forum, January 2008. http://www.fraserinstitute.org/uploadedFiles/fraser-ca/Content/researchnews/research/articles/immigration-national-security-canada-us-relations.pdf (accessed July 16, 2013).

Newark, Scott. "Scott Newark on Immigration and National Security." Straight Talk, January 2013:1-8. July 22, 2013. http://www.macdonaldlaurier.ca/files/pdf/Straight-TalkNewark-Immigration-and-National-Security4.pdf.

Paperny, Anna Mehler. Global News, "Train Terror Suspect Raed Jaser Dodged Deportation for Years.” Last modified April 25, 2013. Accessed July 18, 2013. http://globalnews.ca/news/511849/prior-fraud-conviction-almost-led-to-deportation-ofone-via-rail-terror-suspect/.

PBS, “Ahmed Ressam's Millennium Plot.” Last modified 2013. Accessed August 1, 2013. http://www.pbs.org/wgbh/pages/frontline/shows/trail/inside/cron.html.

Pue, Wesley. "The War on Terror: Constitutional Governance in a State of Permanent Warfare?" Osgoode Hall Law Journal. no. 41 (2003): 267-462.

Rahman, Waheeda, "Canada's Response to the 'War on Terror': A New Era of National Security, Erosion of Rights and Racial Injustice." Theses and dissertations., Ryerson University, 2008. Paper 114, http://digitalcommons.ryerson.ca/dissertations/114/

Refugee Studies Center, "Protracted Refugee Situations.” Last modified January 29, 2012. Accessed July 22, 2013. http://www.prsproject.org/.

Rehaag, Sean. "Judicial Review of Refugee Determinations: The Luck of the Draw?" Queen's Law Journal. no. 1 (2012): 1-58. 
Rekai, Peter. "US and Canadian Immigration Policies- Marching Together to Different Tunes." C.D. Howe Institute Commentary: the Border Papers. no. 171 (2002): 1-25. http://www.cdhowe.org/pdf/temp/rekai.pdf (accessed June 2, 2013).

Russo, Robert M. "Security, Securitization and Human Capital: The New Wave of Canadian Immigration Laws." International Journal of Human and Social Sciences 3, no. 4 (2008): 295-304. Accessed June 12, 2013. http://www.waset.org/journals/ijhss/v3/v3-4-37.pdf.

Showler, Peter. "Fast, Fair and Final: Reforming Canada's Refugee System." Working paper. 128, The Maytree Foundation, 2009. Accessed July, 13, 2013. http://www.cdphrc.uottawa.ca/projects/refugee-forum/publications/FastFairAndFinal.pdf.

---, Peter. Human Rights Research and Education Centre: Refugee Forum, "By the Numbers: Refugee Statistics." Accessed August 1, 2013. http://www.cdphrc.uottawa.ca/projects/refugee-forum/projects/Statistics.php.

Stoffman, Daniel. Who Gets In: What's Wrong with Canada's Immigration Program and How to Fix it. Toronto: Macfarlane Walter \& Ross, 2002.

Story, Brett. "Politics as Usual: The Criminalization of Asylum Seekers in the United States." Master Thesis., University of Oxford, 2005. Accessed July 7, 2013. http://www.rsc.ox.ac.uk/publications/working-papersfolder_contents/RSCworkingpaper26.pdf.

Stritzel, Holger. "Towards a Theory of Securitization: Copenhagen and Beyond." European Journal of International Relations. no. 3 (2007): 357-383.

Taureck, Rita. "Securitization Theory and Securitization Studies." Journal of International Relations and Development. no. 9 (2006): 53-61.

UK Border Agency, "When Do I Have a Right to Appeal." Last modified 2012. Accessed July 17, 2013.

http://www.ukba.homeoffice.gov.uk/asylum/outcomes/unsuccessfulapplications/appeals/r ighttoappeal/.

United Nations, "The Universal Declaration of Human Rights." Last modified 2013. Accessed June 26, 2013. http://www.un.org/en/documents/udhr/index.shtml.

United Nations High Commissioner for Refugees (UNHCR). Convention and Protocol Relating to the Status of Refugees. 1951. Accessed June 12, 2013. http://www.unhcr.org/3b66c2aa10.html.

---. Refugees and Others of Concern to UNHCR, 1999 Statistical Overview. Geneva: 2000. http://www.unhcr.org/3ae6bc834.pdf (accessed July 18, 2013). 
United Nations Human Rights, "International Covenant on Civil and Political Rights." Last modified 2013. Accessed August 1, 2013.

http://www.ohchr.org/en/professionalinterest/pages/ccpr.aspx.

United Nations Security Council, "Security Council Unanimously Adopts Wide-Ranging AntiTerrorism Resolution: Calls for Suppressing, Financing, Improving International Cooperation.” Last modified 2001. Accessed July 11, 2013. http://www.un.org/News/Press/docs/2001/sc7158.doc.htm.

Wente, Margaret. "When it comes to refugee claims, it's pretty easy to ID the 'safe' countries." Globe and Mail, sec. Commentary, March 31, 2010. http://www.theglobeandmail.com/commentary/when-it-comes-to-refugee-claims-itspretty-easy-to-id-the-safe-countries/article4321353/ (accessed July 17, 2013).

Wydrzynski, Christopher. "Refugees and the Immigration Act." McGill Law Journal. (1979): 154-192. http://lawjournal.mcgill.ca/documents/25/2/wydryzynski.pdf (accessed July 10, 2013).

Yasenchak, Megan, Jennifer Giglio, and Margaret Paxson. Woodrow Wilson International Center for Scholars, "National Security and Human Rights." Last modified October 2006. Accessed July 21, 2013. www.wilsoncenter.org/sites/default/files/KI_G8.pdf.

Zard, Monette. "Exclusion, Terrorism and the Refugee Convention." Forced Migration Review. (2002): 32-34. 


\section{GLOSSARY}

\begin{tabular}{|l|l|}
\hline CBSA & Canada Border Services Agency \\
\hline CSIS & Canadian Security Intelligence Services \\
\hline CIC & Citizenship and Immigration Canada \\
\hline DCO & Designated Country of Origin \\
\hline FACT & Federation of Associations of Canadian Tamils \\
\hline H\&C & Humanitarian and compassionate consideration \\
\hline IRB & Immigration and Refugee Board \\
\hline IRPA & Immigration and Refugee Protection Act \\
\hline LTTE & Liberation Tigers of Tamil Eelam \\
\hline PFLP & Popular Front for the Liberation of Palestine \\
\hline PRS & Protracted Refugee Situation \\
\hline PRRA & Pre-removal risk assessment \\
\hline RAD & Refugee Appeal Division \\
\hline RCMP & Royal Canadian Mounted Police \\
\hline RPD & Refugee Protection Division \\
\hline
\end{tabular}

